\title{
Geomorphic process fingerprints in submarine canyons
}

\author{
Daniel S. Brothers *, Uri S. ten Brink, Brian D. Andrews, Jason D. Chaytor, David C. Twichell \\ Woods Hole Coastal and Marine Science Center, US Geological Survey, 384 Woods Hole Rd, Woods Hole, MA 02559, United States
}

\section{A R T I C L E I N F O}

\section{Article history:}

Received 4 June 2012

Received in revised form 16 January 2013

Accepted 28 January 2013

Available online 7 February 2013

Communicated by D.J.W. Piper

\section{Keywords:}

turbidity flow

debris flow

multibeam bathymetry

regression

power law

landslide

\begin{abstract}
A B S T R A C T
Submarine canyons are common features of continental margins worldwide. They are conduits that funnel vast quantities of sediment from the continents to the deep sea. Though it is known that submarine canyons form primarily from erosion induced by submarine sediment flows, we currently lack quantitative, empirically based expressions that describe the morphology of submarine canyon networks. Multibeam bathymetry data along the entire passive US Atlantic margin (USAM) and along the active central California margin near Monterey Bay provide an opportunity to examine the fine-scale morphology of 171 slope-sourced canyons. Log-log regression analyses of canyon thalweg gradient $(S)$ versus up-canyon catchment area $(A)$ are used to examine linkages between morphological domains and the generation and evolution of submarine sediment flows. For example, canyon reaches of the upper continental slope are characterized by steep, linear and/or convex longitudinal profiles, whereas reaches farther down canyon have distinctly concave longitudinal profiles. The transition between these geomorphic domains is inferred to represent the downslope transformation of debris flows into erosive, canyon-flushing turbidity flows. Over geologic timescales this process appears to leave behind a predictable geomorphic fingerprint that is dependent on the catchment area of the canyon head. Catchment area, in turn, may be a proxy for the volume of sediment released during geomorphically significant failures along the upper continental slope. Focused studies of slope-sourced submarine canyons may provide new insights into the relationships between fine-scale canyon morphology and down-canyon changes in sediment flow dynamics.
\end{abstract}

Published by Elsevier B.V.

\section{Introduction}

The geomorphic evolution of continental margins and, in particular, the formation of submarine canyons are heavily influenced by the interplay between sedimentary mass flows and seafloor topography (Mitchell, 2005; Ramsey et al., 2006; Gerber et al., 2009; Paull et al., 2013). However, direct observations of dynamic erosion from sediment flows are rare (Paull et al., 2003; Xu et al., 2004) and our understanding of canyon erosion mechanisms is based largely on laboratory and analytical inferences (Kneller and Buckee, 2000; Mohrig and Marr, 2003; Gerber et al., 2009). Many of the principal studies aimed at understanding the origins and evolution of submarine canyons were either focused on a select number of the large, predominantly shelf-sourced canyon systems (Shepard and Emery, 1973; Farre et al., 1983; Gardner, 1989; Piper and Savoye, 1993; Greene et al., 2002; Pirmez and Imran, 2003; Puig et al., 2004; Paull et al., 2011), or on a mixture of shelf- and slope-sourced canyons having relatively limited spatial extent and bathymetric resolution (Shepard, 1981; Pratson et al., 1994; Pratson and Coakley, 1996; Mitchell, 2004, 2005; Ramsey et al., 2006; Straub et al., 2007; Paull et al., 2011, 2013). Slope-sourced canyons are assumed to be fully decoupled from onshore drainage systems, whereas the larger and older shelf-sourced canyons that extend shoreward of the classically defined shelf-edge (Kennett, 1982). To study the linkages

\footnotetext{
* Corresponding author. Tel.: +1 5084572293.

E-mail address: dbrothers@usgs.gov (D.S. Brothers).
}

between form and process, these two classes of submarine canyons should be studied separately because they evolve under fundamentally different boundary conditions and perhaps over very different timescales (Twichell and Roberts, 1982; Farre et al., 1983).

In this study, we explore the relationship between channelized mass flows and the development of submarine canyon network morphology using an enormous volume of continuous, high-resolution bathymetric data from two separate settings: the US Atlantic and Central California continental margins (Fig. 1). Our aim is to address the following fundamental questions: (1) is there an objective way to define the head-ward extent of submarine canyon networks? (2) Do submarine canyon networks have consistent and predictable patterns regardless of setting? (3) Can we use canyon network scaling relations to identify different process domains that relate to the dynamic behavior of submarine sediment flows?

\section{Submarine mass flows and canyon network morphology}

The dominant process responsible for submarine canyon formation is the tendency of sediment flows to channelize into avenues of concentrated erosion (Pratson and Coakley, 1996). Submarine landslides generated by failure of unstable sediments in and around canyon heads and along steep canyon walls can accelerate and entrain water as they move downslope and can transform into erosive turbidity flows (Hampton, 1972; Mohrig et al., 1998; Piper et al., 1999; Mohrig and Marr, 2003). Over time, repeated turbidity flows erode networks of 

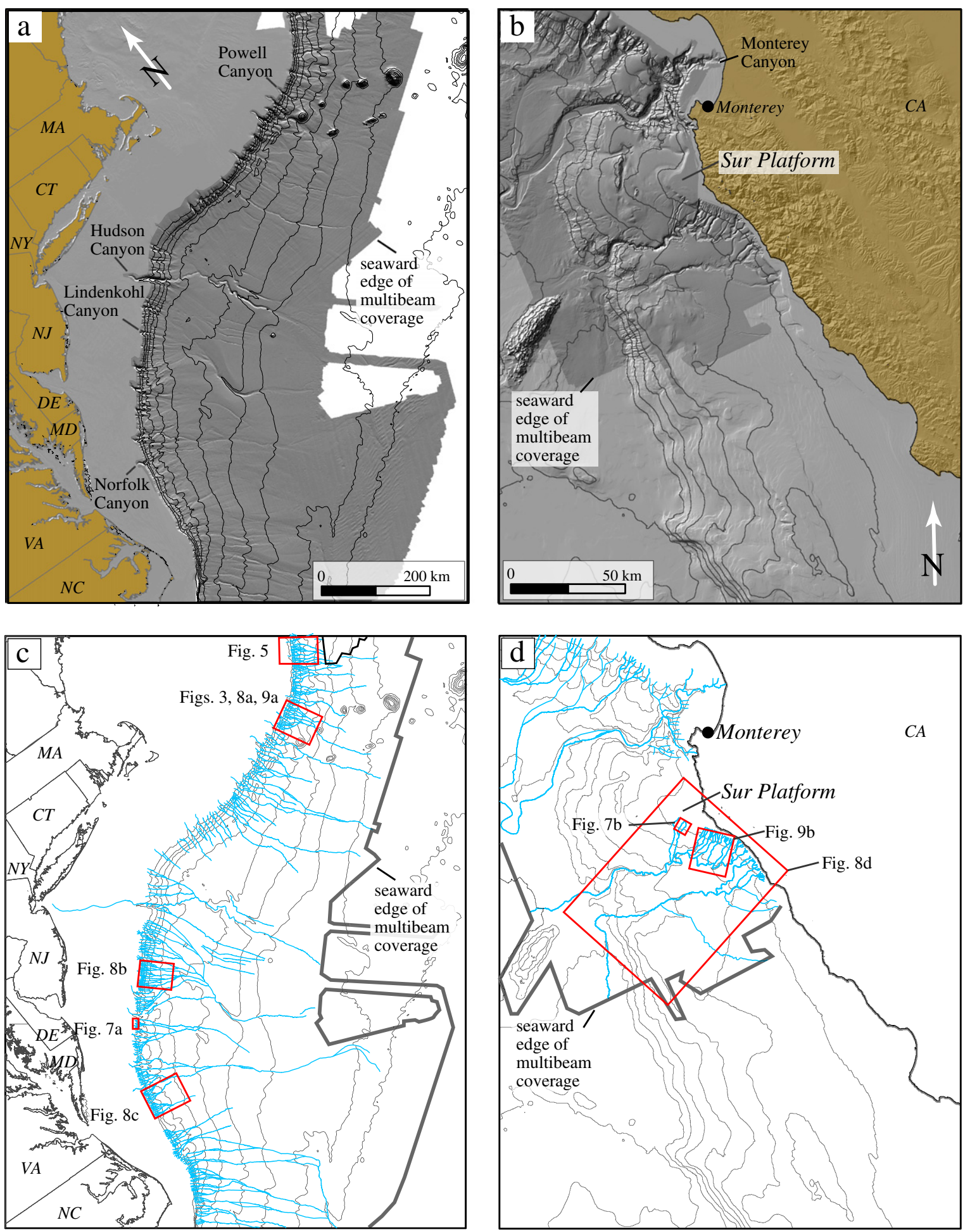

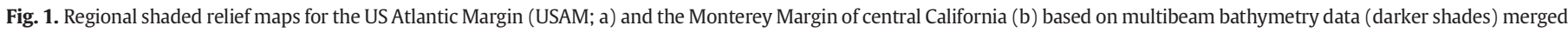

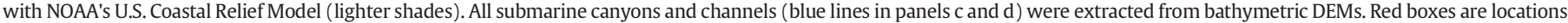
of subsequent figures. All contours have $500 \mathrm{~m}$ vertical spacing.

canyons across the continental slope and rise whose bathymetric expressions resemble topography of terrestrial channel networks (Belderson and Stride, 1969; Mcgregor et al., 1982; Twichell and Roberts, 1982; Pratson and Coakley, 1996; Mitchell, 2005).

Terrestrial researchers have created conceptual and theoretical models to describe the evolution of drainage basins and to delineate geomorphic process domains. Hillslopes and stream valleys represent the most significant features in terms of drainage basin evolution
(Willgoose et al., 1991a, 1991b; Tucker and Bras, 1998; Whipple and Tucker, 2002; Stock and Dietrich, 2003). Hillslope domains tend to be located in and around channel heads and near drainage divides. They are characterized by soil creep, debris flows and landslides across topographic surfaces having relatively steep gradients and small catchment areas (Howard, 1994). In contrast, stream valley domains appear below hillslope domains and their morphology is dominated by erosion due to overland flow. Stream-bed shear stresses increase with flow discharge 
and/or thalweg gradient. When high quality topographic data is available in terrestrial environments, drainage area is commonly used as a proxy for stream discharge, allowing the magnitude of stream bed shear tress at a given location to be defined as a function of catchment area and local thalweg gradient (Seidl and Dietrich, 1992; Tucker and Bras, 1998; Whipple and Tucker, 2002; Wobus et al., 2006).

A standard approach in fluvial geomorphology is to measure the local thalweg gradient $(S)$ and the associated catchment area $(A)$ at discrete points along a longitudinal channel profile (e.g., Kirby and Whipple, 2001). The transport capacity, $Q_{s}$, of a stream channel can then be approximated as a power function of $A$ and $S$ (Howard, 1994; references therein):

$Q_{S}=K A^{m} S^{n}$

where $K, m$ and $n$ are constants. In a steady state landscape, $Q_{s}$ is balanced by the tectonic uplift rate, $U$, and the long-term sediment transport through any location must equal the product of uplift rate and contributing catchment area. Eq. (1) can be rearranged into a generalized form relating catchment area to local thalweg gradient (Tucker and Whipple, 2002; references therein):

$S=K_{S} A^{-\theta_{i}}$

$K_{s}$ and $\theta_{i}$ are the channel steepness $(\mathrm{m} / \mathrm{m})$ and intrinsic concavity indices, respectively. Segments of an individual stream profile characterized by different values for $\theta_{i}$ and/or $K_{s}$ are often used to identify downstream thresholds of process dominance (Howard, 1994; Tucker and Bras, 1998) and to examine the responses of landforms to tectonic uplift and climate change (Whipple and Tucker, 2002). Both parameters are estimated by applying least squares regression to log-log scatter plots of $A$ versus $S$ : $\theta_{i}$ is the slope of the regression curve and $K_{S}$ is the $\mathrm{y}$-intercept. For example, the first kink in $S-A$ regression plots (small $A$ and large $S$; Fig. 2) is widely interpreted to represent a geomorphic threshold separating landscapes that are dominated by hillslope processes from those dominated by fluvial incision and valley formation (Tucker and Bras, 1998; Stock and Dietrich, 2003). Hillslope domains tend to have linear or convex longitudinal profiles $\left(\theta_{i}<0\right)$ whereas stream valleys have concave profiles ( $\theta_{i}$ typically ranges between 0.3 and 0.6), meaning the thalweg gradient decreases exponentially with increasing area. The threshold separating these domains typically occurs where the catchment area exceeds $\sim 10^{6} \mathrm{~m}^{2}$ (Tucker and Whipple, 2002). Additional thresholds in the $S-A$ plots occur at larger drainage areas and have been linked with changes in fluvial sediment transport capacity, such as the transition from supply limited to transport limited domains (Whipple and Tucker, 2002; Fig. 2).

In the marine realm, the uppermost continental slope is often characterized by steep, convergent topography associated with submarine canyon heads. Sediment movement in and around canyon heads and along inter-canyon ridges is dominated by diffusive transport and small-scale landsliding (Pirmez et al., 1998; Mitchell and Huthnance, 2007). Seabed observations suggest that canyon heads contain pervasive evidence for retrogressive failures, debris flow deposits and steep, narrow gullies that converge downslope into deeply entrenched canyon valleys. Canyon valleys are thought to form primarily by turbidity current erosion. However, few studies have investigated the morphological connection between retrogressive failures in and around slope-sourced canyon heads and the generation of turbidity flows that scour and erode canyon valleys of the continental slope (Twichell and Roberts, 1982; Farre et al., 1983; Pratson et al., 1994; Piper and Normark, 2009). Canyon relief generally diminishes along the lowermost slope/upper rise where mass flow deposition and aggradation of leveed channel systems begin to dominate (Galloway, 1998).

Within the context of slope depositional systems, submarine canyon networks can be segregated based on the primary source of the sediment transported down canyon (i.e., allochthonous versus autochthonous a

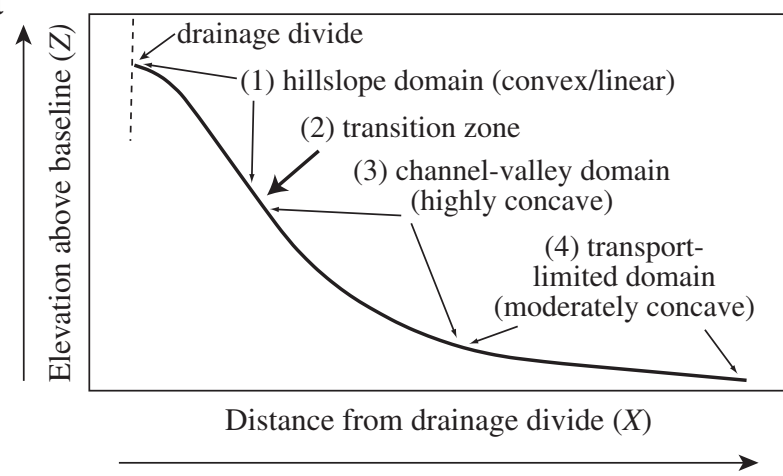

b

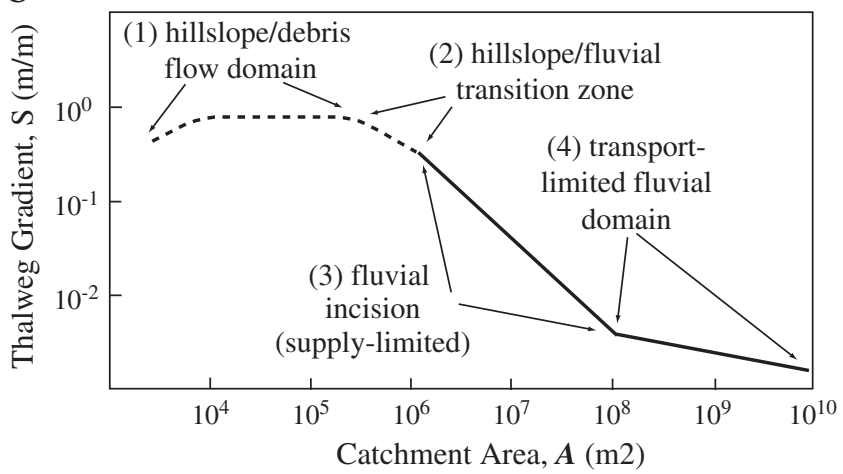

Fig. 2. Hypothetical thalweg profile and associated topographic signatures for a terrestrial channel network. Catchment area $(A)$ and channel gradient $(S)$ are measured at discreet points along a stream profile (a) and plotted in log-log space to examine power-law scaling parameters (b); on Whipple and Tucker (1999), Whipple and Tucker (2002), Stock and Dietrich (2003). Soil creep, debris flows and landslides dominate erosion in steep channelheads where catchment area is less than $\sim 10^{6} \mathrm{~m}^{2}$ (dashed line). Increasing fluvial discharge downstream is the dominant erosion mechanism in the channel-valley domains (solid black line).

systems). The shelf-edge delineates a major hydrographic boundary separating wave and current driven sediment transport on the shelf from gravity driven transport of the slope (Pirmez et al., 1998). We define shelf-sourced canyons as those that extend landward of the continental shelf-break and have higher propensity to capture sediment transported by shelf processes and/or by direct connections to terrestrial drainage systems (Shepard and Emery, 1973; Shepard, 1981; Mulder and Syvitski, 1995; Johnson et al., 2001). In contrast, slope-sourced canyons have heads located along the uppermost continental slope and are assumed to evolve primarily from erosion induced by local slope failures and mass flows sourced from within the canyon network (Twichell and Roberts, 1982; Pratson et al., 1994; Pratson and Coakley, 1996; Goff, 2001; Brothers et al., in press). Hypothetical drainage divides for slopesourced canyon networks can be delineated along the uppermost slope. We assume that sediment entering canyon networks is sourced from within the network, then carefully extract and analyze the canyon network morphology using a geomorphic framework developed by terrestrial studies.

Previous studies used digital elevation models (DEMs) derived from multibeam bathymetry data to examine the $S-A$ scaling parameters, longitudinal thalweg profiles and erosion processes in submarine canyons, but yielded mixed results (Pratson and Ryan, 1996; Mitchell, 2005; Ramsey et al., 2006; Straub et al., 2007). Mitchell (2005) observed an inverse power-law relationship in $S-A$ regression plots and developed an erosion model in which hemipelagic sediments accumulate on the walls of canyons until they become unstable and initiate erosive sedimentary flows. It was speculated that a steady-state canyon configuration develops due to a balance between slope aggradation and canyon entrenchment. The frequency and size of erosive flows increase 
down-canyon, which increase cumulative erosion in a way that is analogous to increased stream discharge with catchment area in fluvial geomorphology.

\section{Methods}

We apply DEM-based geomorphic analysis (e.g., Wobus et al., 2006) to an enormous volume of multibeam bathymetry data from both passive and active margin settings. Along the passive USAM, bathymetric data were collected during 26 separate geophysical cruises covering approximately $616,000 \mathrm{~km}^{2}$ of the slope and rise between Georges Banks and the Blake Plateau (Fig. 1a, c; Andrews et al., 2013; Brothers et al., in press). We used a continuous $100-\mathrm{m}$ resolution DEM for most of the quantitative analysis, but several sub-regions along the upper slope were gridded at 10 and $25 \mathrm{~m}$ for detailed qualitative interpretations of canyon head morphology. Along the active central California margin, significant along-strike tectonic variation occurs (Greene et al., 2002), so our analysis was limited to a $7500 \mathrm{~km}^{2}$ region located to the southwest of Monterey Bay, just offshore of the Sur Platform (Fig. 1b, d). Multibeam bathymetry data (Hatcher et al., 2000; Greene et al., 2002; Wong and Eittreim, 2002) were gridded at $25 \mathrm{~m}$ for quantitative analysis and $5 \mathrm{~m}$ for detailed qualitative interpretations of outer shelf and upper slope morphology.

Because slope-sourced canyon heads are located at variable depths below the shelf-edge, using a single bathymetric contour to define the upper-slope drainage divides (Mitchell, 2005; Straub et al., 2007) may lead to incorrect estimates of canyon head catchment areas. A hypothetical uncanyonized DEM was constructed by interpolating a surface across the crests of canyon interfluves and inter-canyon plains of the outer shelf and slope. This surface also allowed us to examine the first-order shape of the uncanyonized continental slope, or "interfluve" surface (Brothers et al., in press). Canyon relief was defined as the relative elevation difference between the canyon thalweg and the hypothetical uncanyonized surface. In other words, relief is measured from the thalweg to the crest of the adjacent inter-canyon ridges. Drainage divides along the uppermost continental slope were interpreted based on fine-scale canyon head morphology and local bathymetric relief. Canyon head relief was used to guide manual selection of drainage divides along the outer shelf and uppermost continental slope (e.g., Fig. 3); drainage divides were selected where relief along the upper rim of canyon heads exceeded $10 \mathrm{~m}$. Uncertainties associated with drainage divide selection are estimated to produce errors in catchment area of less $0.5 \mathrm{~km}^{2}$. Next, using the hypothetical drainage divides, bathymetric DEMs were split into drainage basins using flow accumulation arrays and watershed analysis tools in ARC/INFO. Initially, all submarine canyons and channels were extracted from the bathymetric DEMs (Fig. 1c, d) and used to differentiate between shelf-sourced and slope-sourced canyons in each study region.

Thalweg depth, gradient $(S)$, canyon relief and catchment area $(A)$ were extracted at every $20 \mathrm{~m}$ contour down the thalweg of each slope-sourced canyon. Because of the similarities between fluvial drainages and submarine canyon networks, we assumed from the beginning that canyon network morphology can be described by power-law scaling relations between gradient and catchment area and did not perform sensitivity analysis aimed at testing other empirical models. Regression analysis was applied to $S-A$ scatter plots of each individual canyon for a total of 120 canyons along the USAM and 51 canyons along the Sur Platform. The regression analysis of $\log -\log S-A$ scatter plots involved a certain degree of inherent subjectivity because the limits for each fit were selected manually across groupings of points that appeared to follow a linear trend for at least one order of magnitude in either catchment area or gradient. Picks were guided by a log-binned running average of $S-A$ points in an effort to reduce subjective bias in the identification of distinctive linear segments (e.g., Fig. 4; Wobus et al., 2006). A measure of variance $\left(R^{2}\right)$ was computed for each regression segment within each individual canyon. Estimates for $\theta_{i}$ along each regression segment and the $S-A$ values for segment boundaries for each individual canyon were saved to a database. Basic statistics were computed for all segments identified along both margins (Table 1). Interpretations were based on correlations between distinct regression segments and geologic features identified within specific reaches of submarine canyons.

\section{Results}

\subsection{S-A analysis of slope-sourced canyons}

Examples of characteristic canyon profiles and their associated $S-A$ regression analyses are shown in Figs. 4 and 5. To first-order, the log$\log$ plots of $S-A$ data for each of the slope-sourced canyons on both margins display patterns that are similar to those observed in terrestrial drainage networks (Fig. 2a). Regression analysis suggests that USAM canyons exhibit an average of four distinctive concavity segments and Sur Platform canyons are characterized by three measureable segments, plus a fourth segment along the lowermost slope that was not measured due to its extreme variation and convexity. The steepest segments of canyon profiles are located along the uppermost continental slope. Regression analysis of these segments yields concavity estimates that are approximately zero $\left(\theta_{i} \simeq 0\right)$ or slightly negative $\left(\theta_{i}<0\right)$, meaning the associated longitudinal profiles are either linear or slightly convex (Figs. 4 and 5). Some canyons contain a short convex segment just below the drainage divide that becomes linear farther downslope (e.g., Fig. 5). An abrupt transition in $\theta_{i}$ is observed on both margins and marks the change from linear/convex to highly concave profiles $\left(\theta_{i}>0\right)$. For descriptive purposes (see Discussion for explanations) we apply the following nomenclature to distinguish between segments. The steep, canyon segments located immediately below the drainage divides and characterized by convergent topography are considered to be within the "landslide" domain, the transition between linear/convex and concave canyon profiles (intersection of the two regression lines) will be called "threshold-1", and the concave segments below threshold-1 are associated with the "canyon-valley" domain (Figs. 4 and 5). The scaling parameters estimated for each regression segment within each individual canyon were averaged to produce composite $S-A$ power-law functions (Fig. 6) and to identify physical parameters associated with boundaries between different segments.

Threshold- 1 was relatively straightforward to identify for almost every canyon (e.g., Figs. 4-6). $S-A$ values for threshold-1 (termed $S_{t}$ and $A_{t}$ ) were manually picked from individual plots of each canyon. We estimate the average uncertainty in $S_{t}$ and $A_{t}$ picks to be less than $10 \%$. For the USAM (Fig. $6 a$ ): $S_{t}$ ranges from $2.9^{\circ}$ to $10.1^{\circ}$ and has a median value of $7.3^{\circ} ; A_{t}$ ranges from $1.8 \mathrm{~km}^{2}$ to $128.1 \mathrm{~km}^{2}$ with a median of $8.8 \mathrm{~km}^{2}$. For Sur Platform canyons (Fig. $6 \mathrm{~b}$ ): $S_{t}$ ranges from $5.1^{\circ}$ to $23.7^{\circ}$ with a median value of $11.3^{\circ} ; A_{t}$ ranges from $0.1 \mathrm{~km}^{2}$ to $8.5 \mathrm{~km}^{2}$ with a median of $0.4 \mathrm{~km}^{2}$. A log-log scatter plot of threshold- 1 values (Fig. 6c) reveals distinct distributions for the separate margins, but also an overall trend consistent with both datasets. The USAM data spans greater catchment areas and smaller gradients, whereas the Sur Platform data spans small areas and gradients. A combined fit yields an interesting trend in which the gradient decreases exponentially with increasing area in the form of $S_{t}=2.09 A_{t}^{-0.18}\left(R^{2}=0.69\right)$.

Seafloor morphology within the landslide domains of both margins is dominated by gullies, debris flow channels and irregular surfaces associated with sinuous failure scarps (10-20 m high; Fig. 7). Such features lead to considerable variation in $S$ and result in relatively low $\mathrm{R}^{2}$ values (0.4-0.5 on average) in the regression analyses. Along the USAM, small pockmarks (100-200 m diameter) cover the seafloor surrounding the landslide domain (Fig. 7a), particularly along the uppermost continental slope. Canyon segments located within the landslide domains occur between the shelf-edge and water depths up to $1600 \mathrm{~m}$ and vary in length depending on the geometry of the catchment above threshold-1 (Figs. 5-8). Narrow landslide catchments appear to be associated with longer canyon segments that extend to greater depths than 


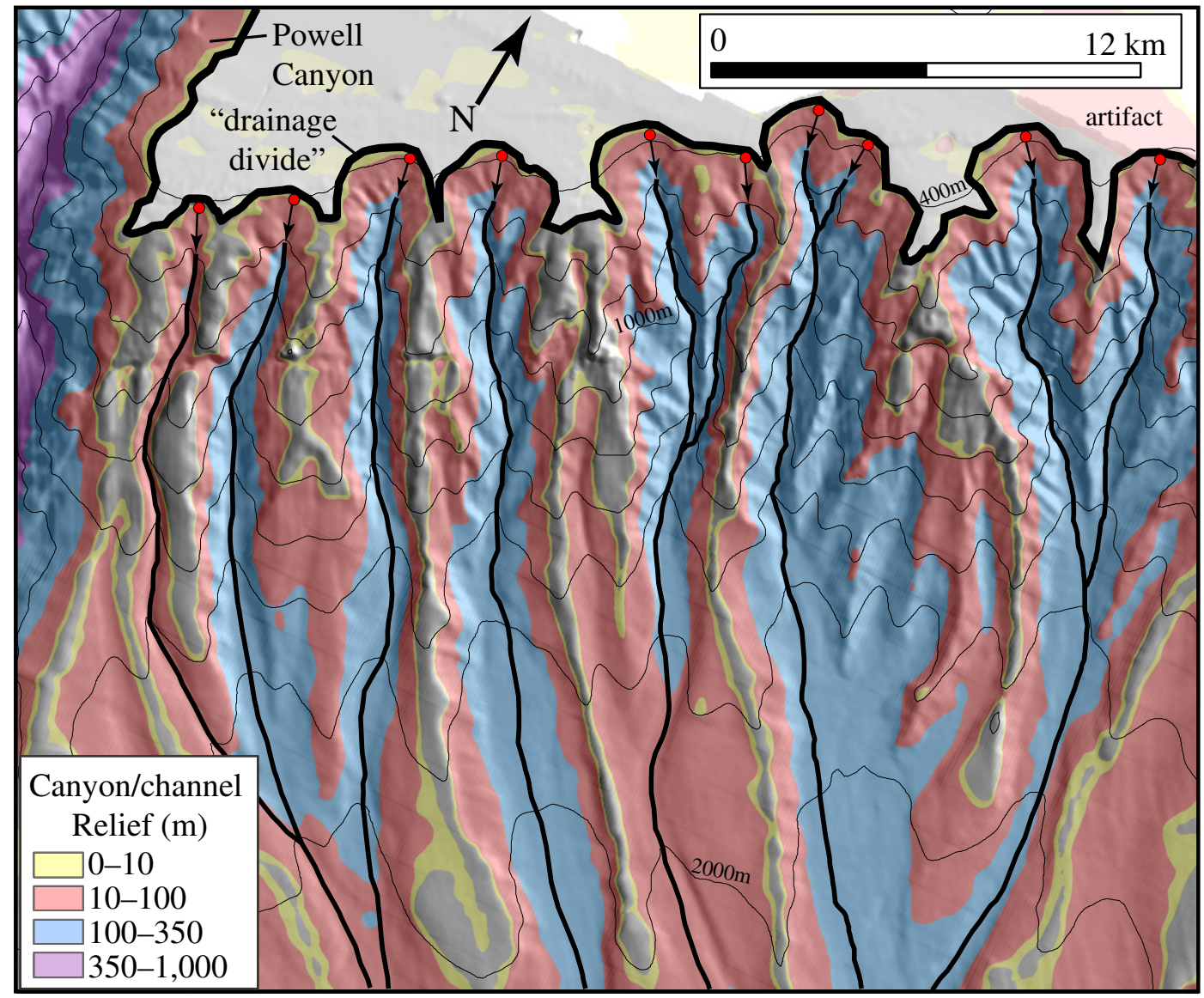

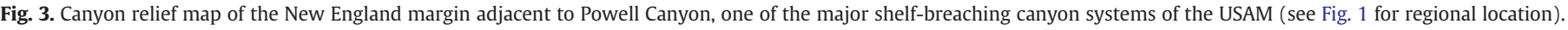

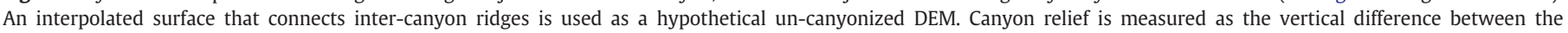
un-canyonized surface and the true bathymetry. Bold, black line above canyon heads (red dots) represents the drainage divide. Bathymetric contours are marked every 200 m.

the wider, shorter catchments. However, the area of individual landslide domains does not appear to be related to shape (Fig. 5). The average thalweg gradient of canyons and gullies within the landslide domain is $10.2^{\circ} \pm 1.8^{\circ}$. More than $70 \%$ of the total terrain located within landslide catchment areas is steeper than $8^{\circ}$ and more than $95 \%$ of the terrain is steeper than $5^{\circ}$.

In contrast, along the Sur Platform the average gradient of canyon thalwegs within the landslide domain is $13.5^{\circ} \pm 3.7^{\circ}$. Segments are relatively short and extend from the shelf edge down to a maximum depth of $\sim 400 \mathrm{~m}$ (e.g., Figs. 4 and 7b). The seafloor along canyon walls contains fewer gullies and landslide scars than the USAM canyons, but the steep slopes near canyon heads show evidence for slope failures. Canyon heads are separated from the shelf break by a scarp at $\sim 160$-m depth. The terraced appearance of the shelf break is associated with exposed, more resistant substrate (Eittreim et al., 2002).

Canyon relief generally increases downslope as narrow gullies within the landslide domain converge and transition into canyon-valley domains located downslope of threshold-1. The canyon-valley segments can be fit relatively well by an inverse power-law $\left(\theta_{i}>0\right)$, despite typically convex shapes of the adjacent canyon interfluves (e.g., Fig. 4). The canyon-valley domains of the USAM canyons contain three primary regression segments with average concavities of $\theta_{i A 1}=0.65 \pm 0.06, \theta_{i A 2}=$ $0.39 \pm 0.07$ and $\theta_{i A 3} \leq 0.1$ (Table 1 ; Fig. 6a). Average $\mathrm{R}^{2}$ values for $\theta_{i A 1}$ segments range from 0.5 to 0.89 , with an average of $R^{2}=0.65$. Regression of $\theta_{i A 2}$ and $\theta_{i A 23}$ is significantly worse, with $\mathrm{R}^{2}$ values rarely exceeding 0.5 for either segment. However, much of the variation in $\theta_{i A 1}$ and $\theta_{i A 2}$ is related to outlier $S-A$ data associated with canyon confluences, "knickpoints", and overprint from mass failures along the lower slope and upper rise. Sur Platform canyons have two canyon-valley segments that could be systematically measured using regression analysis. The mean values are $\theta_{i M 1} \simeq 0.44 \pm 0.05, \theta_{i M 2} \leq 0.1$ (Table 1 ; Fig. $6 \mathrm{~b}$ ). $\mathrm{R}^{2}$ values for $\theta_{i M 1}$ segments range from 0.4 to 0.92 , with an average $\mathrm{R}^{2}=0.69 ; \mathrm{R}^{2}$ values for $\theta_{i M 2}$ are between 0.3 and 0.6 and, as noted, regression analysis of the lower slope reaches was not attempted due to the extreme variation and convexity. Simple comparison shows that $\theta_{i M 1} \simeq \theta_{i A 2}$ and $\theta_{i M 2} \simeq \theta_{i A 3}$.

Though a more comprehensive analysis is needed, canyons with larger catchment areas at threshold-1 appear to have higher concavities and higher relief along the first canyon-valley segment. Canyon reaches with gradients $>5^{\circ}$ tend to have v-shaped cross-sections and those with gradients $<3^{\circ}$ are often flat-bottomed or U-shaped. Off the Sur Platform, canyon gradients decrease to less than $5^{\circ}$ within $2.5 \mathrm{~km}$ of threshold-1, whereas most of the USAM canyons drop below $5^{\circ}$ between 5 and $12 \mathrm{~km}$ down canyon of threshold- 1 .

The segment of greatest intrinsic concavity along USAM canyons, $\theta_{i A 1}$, is confined to the continental slope and uppermost rise (Fig. 8a-c). In general, the boundary between $\theta_{i A 1}$ and $\theta_{i A 2}$ appears to coincide with either the change in thalweg gradient or a drop-off in canyon relief associated with the slope-rise transition along the inter-canyon ridges. Across-canyon bathymetric profiles along $\theta_{i A 1}$ are relatively narrow and bounded by steep walls (Fig. 9a). They are mostly v-shaped between depths of about $500-1500 \mathrm{~m}$, then become flat bottomed as they transition to $\theta_{i A 2}$ canyon reaches along the lower slope and uppermost rise. $\theta_{i A 3}$ segments begin along the continental rise in depths $>2500 \mathrm{~m}$ and are associated with deep-sea channels. Channels that do not merge with major shelf-sourced canyon-channel systems are characterized by low 
a
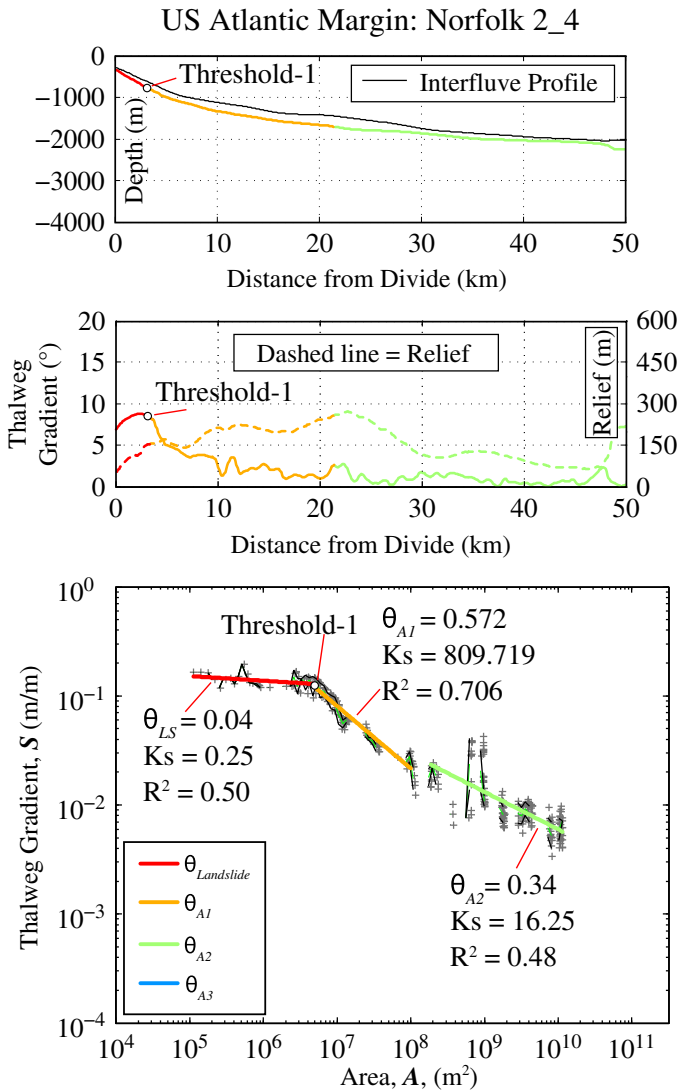

b
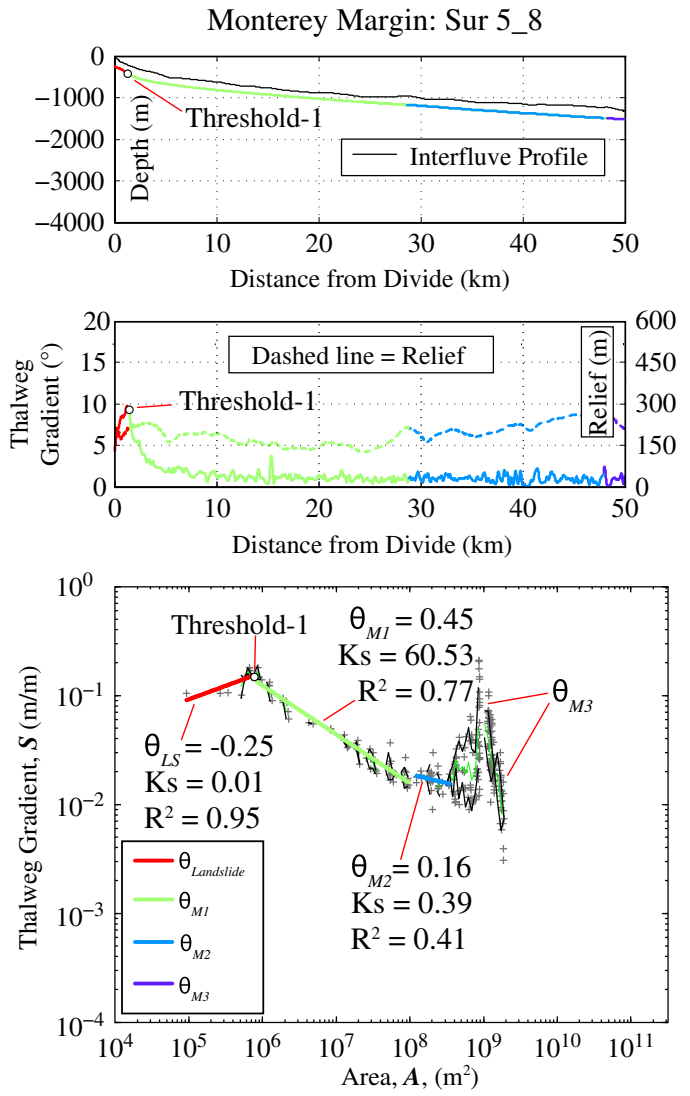

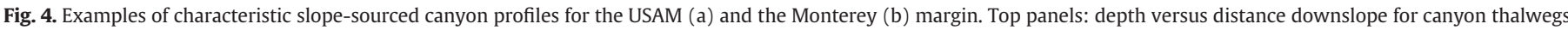

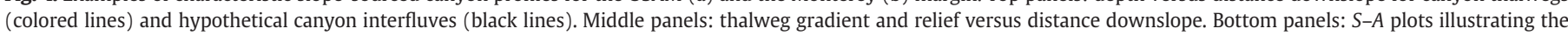

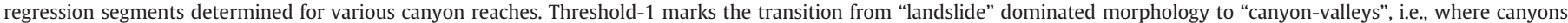
change from having linear or convex profiles to concave profiles.

relief and low gradients $\left(<1^{\circ}\right)$. Sediment waves, failure scars and landslide deposits characterize the surrounding seafloor (Fig. 8a-c). Some channels appear to be infilled and their bathymetric expression disappears on the upper rise; others have subtle morphology that can be traced $10 \mathrm{~s}$ of $\mathrm{km}$ seaward of the base of the slope.

Canyon reaches of the Monterey margin corresponding to concavity segment $\theta_{M 1}$ are confined to the upper slope and many exhibit broad meanders (Fig. 8d). Cross-sections show mixed v-shaped and flat-bottomed profiles, with v-shaped profiles concentrated headward (Fig. 9b). Interfluve longitudinal profiles are convex along the uppermost slope and then appear to parallel their adjacent canyon profiles across the middle slope (e.g., Fig. 4b). Longitudinal profiles show nearly constant gradients along the $\theta_{\mathrm{M} 2}$ reaches, then the gradient increases rapidly to more than $10^{\circ}$ as the $\theta_{M 3}$ reach crosses the lower slope (Figs. $4 \mathrm{~b}, 6 \mathrm{~b}$ and $8 \mathrm{~d}$ ).

Table 1

Summary of power law scaling parameters estimated for canyons of the US Atlantic Margin and the Monterey Margin.

\begin{tabular}{|c|c|c|c|c|c|}
\hline \multirow[t]{3}{*}{ Margin } & \multirow[t]{3}{*}{$\begin{array}{l}\text { Number of } \\
\text { canyons }\end{array}$} & \multicolumn{2}{|c|}{$\begin{array}{l}\text { Threshold-1 } \\
(S t, A t)\end{array}$} & \multirow{2}{*}{\multicolumn{2}{|c|}{$\begin{array}{l}\text { Canyon-valley segments } \\
\text { Mean concavities }\end{array}$}} \\
\hline & & \multirow{2}{*}{$\begin{array}{l}\text { Median } \\
\text { gradient }\end{array}$} & \multirow{2}{*}{$\begin{array}{l}\text { Median } \\
\text { area }\end{array}$} & & \\
\hline & & & & 1st segment & 2nd segment \\
\hline US Atlantic & 120 & $7.3^{\circ}$ & $8.8 \mathrm{~km}^{2}$ & $\theta_{A 1}=0.65 \pm 0.06$ & $\theta_{A 2}=0.39 \pm 0.07$ \\
\hline Monterey, CA & 51 & $11.3^{\circ}$ & $0.4 \mathrm{~km}^{2}$ & $\theta_{M 1}=0.44 \pm 0.05$ & $\theta_{M 2}=<0.1$ \\
\hline
\end{tabular}

\section{Discussion}

Studies by Mitchell $(2004,2005)$ and Ramsey et al. (2006) provided compelling evidence that canyon network scaling relations can be used to identify process boundaries and to develop empirical erosion laws. In spite of this, subsequent modeling results suggested that erosion caused by channelized turbidity flows is not dependent on catchment area (Gerber et al., 2009) and that canyon morphology does not support a landslide driven connection to catchment area (Straub et al., 2007). These studies (Straub et al., 2007; Gerber et al., 2009) did not emphasize the genetic differences between the shelf-sourced and slope-sourced canyons that were used in their analyses and the resolution and spatial extent their data were relatively limited. Therefore, rejecting terrain network scaling relations in studies of submarine canyon evolution may be premature.

\subsection{Implications of landslide domains and threshold-1}

Valley incision by debris flows is an important process within the steep, upland reaches of terrestrial river networks (Stock and Dietrich, 2003). In regions with slopes steeper than $\sim 0.10 \mathrm{~m} / \mathrm{m}\left(\sim 5^{\circ}\right)$, valley network incision is heavily influenced by debris flow scour and associated with curved log-log plots of $S-A$ data. Abrupt transitions from debris flow mantled upland valleys to fluvially incised bedrock valleys are well documented (Stock and Dietrich, 2003). The transitions occur at catchment areas between $10^{5}$ and $10^{6} \mathrm{~m}^{2}$ and are associated with 


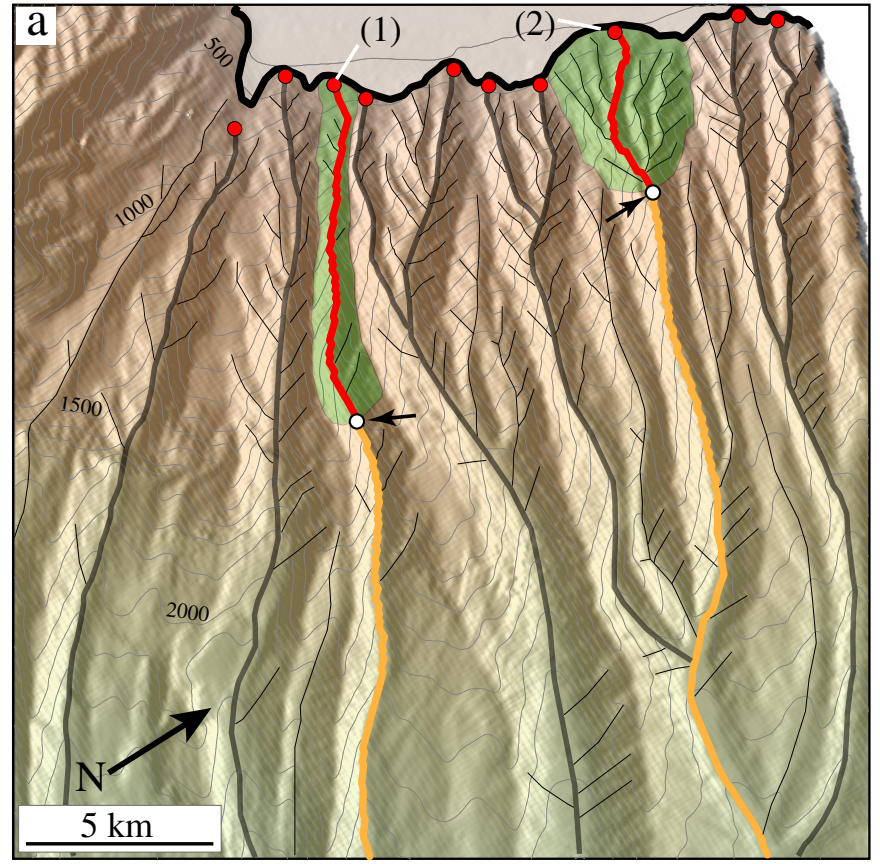

b

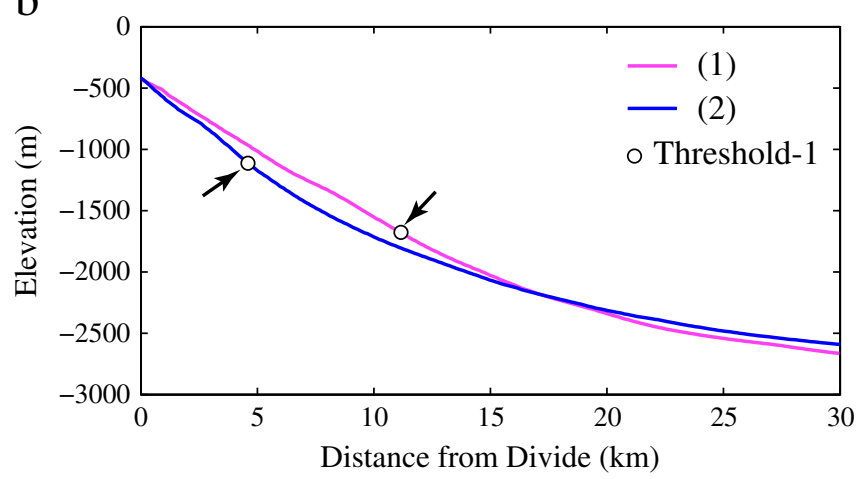

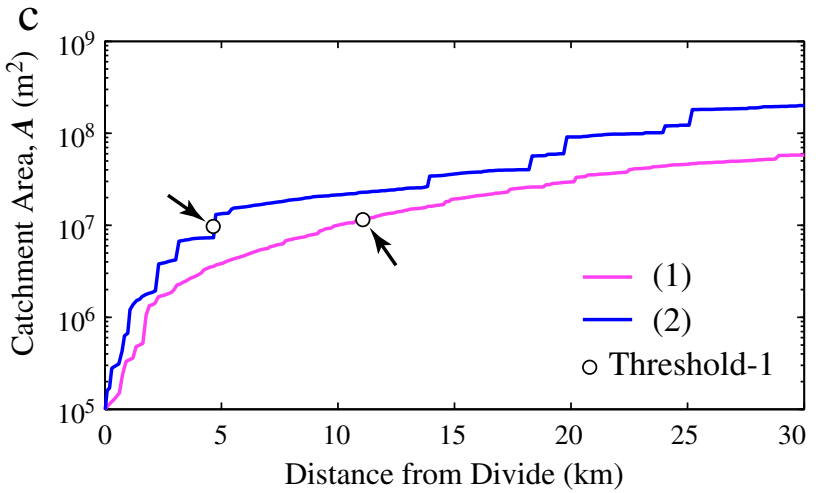

d

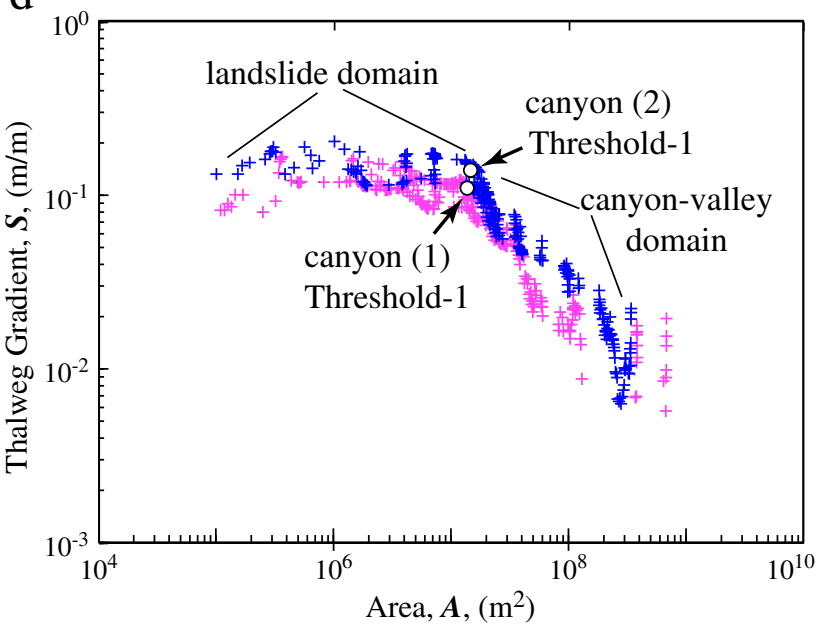

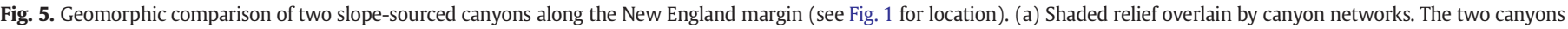

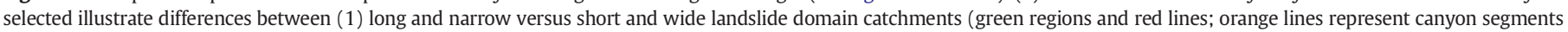

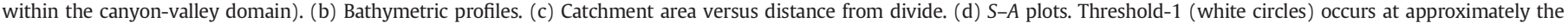
same catchment area in both canyons, but at substantially different depths (1100 m versus $1700 \mathrm{~m})$ and distances from the drainage divide (5 km versus $11 \mathrm{~km}$ ).

distinctive breaks in the $S-A$ scaling parameters (e.g., the transition between segments where $\theta_{i} \simeq 0$ to segments where $0.3 \leq \theta_{i} \leq 0.6$; Fig. 2b). We present a similar scenario for the submarine environment, but our geomorphic interpretations are focused on the behavior of subaqueous debris flows and turbidity flows (e.g., Ramsey et al., 2006). We propose that debris flow incision dominates within the landslide domain of slope-sourced canyons and has an $S-A$ signature distinct from that of canyon-valleys farther downslope. The scaling break separating the two domains may represent the critical point at which geomorphically significant debris flows (i.e., those that leave behind a lasting fingerprint) transform into turbidity flows.

Sediment released by slope failures is expected to accelerate, break up and transform into turbidity flows (Hampton, 1972). Once turbidity flows are generated, they can become self-accelerating through the entrainment of sediment and water, a process called ignition (Parker et al., 1986). Turbidity flows can erode, entrain and transport loose sediment along the canyon floor to deeper waters. One of the best-documented examples of this transformational process is along the Scotian margin of eastern Canada (Piper et al., 1999; Mosher and Piper, 2007; Piper and Normark, 2009), where it is hypothesized that the 1929 M7.2 Grand Banks Earthquake triggered widespread slope failure along the continental slope. Like the USAM, the seafloor just below the shelf-edge of the Scotian margin contains little evidence for mass wasting, but instead is covered by pockmarks. The slope gradient rapidly increases in and around canyon heads ( $\sim 500-700 \mathrm{~m}$ depth) and the pockmarks give way to failure scars and localized failure deposits. Farther downslope shallow channels and gullies converge into canyon-valleys that are devoid of debris flow deposits. Based on detailed seafloor observations, it is inferred that landslides and debris flows generated within the steep, head-ward reaches of submarine canyons evolved rapidly into turbidity flows, which in turn scoured and flushed loose material from canyon valleys out to deeper waters (Piper et al., 1999; Mosher and Piper, 2007; Piper and Normark, 2009). On the Scotian slope, debris flows generated by the earthquake appear to have transformed into turbidity flows in water depths between 700 and $1500 \mathrm{~m}$, approximately the same depth range as threshold-1 along the USAM canyons. In general, the seafloor morphology and geologic history of the Scotian margin are comparable to those of the USAM.

The spatial association of steep, linear canyon profiles across the uppermost slope, and widespread evidence for sediment failures within canyon heads (e.g., Fig. 7) suggests that mass wasting is the dominant process acting within the landslide domain. These observations imply 
that the linear and convex longitudinal canyon profiles within the landslide domain experience repeated failures between episodes of deposition, and that the profile gradient fluctuates about a slope stability threshold (e.g., Fig. 10) that may be controlled by local geotechnical

a

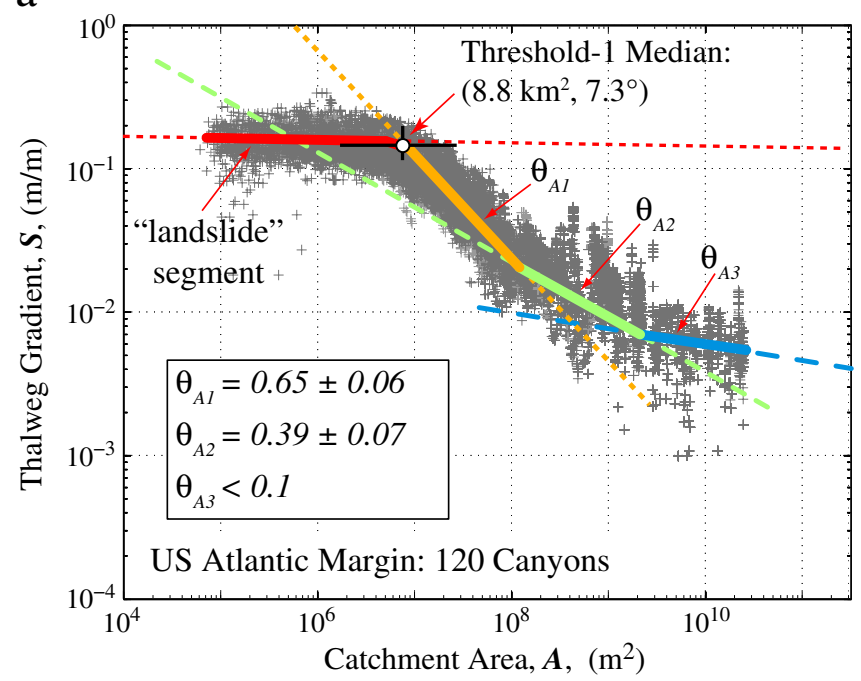

b

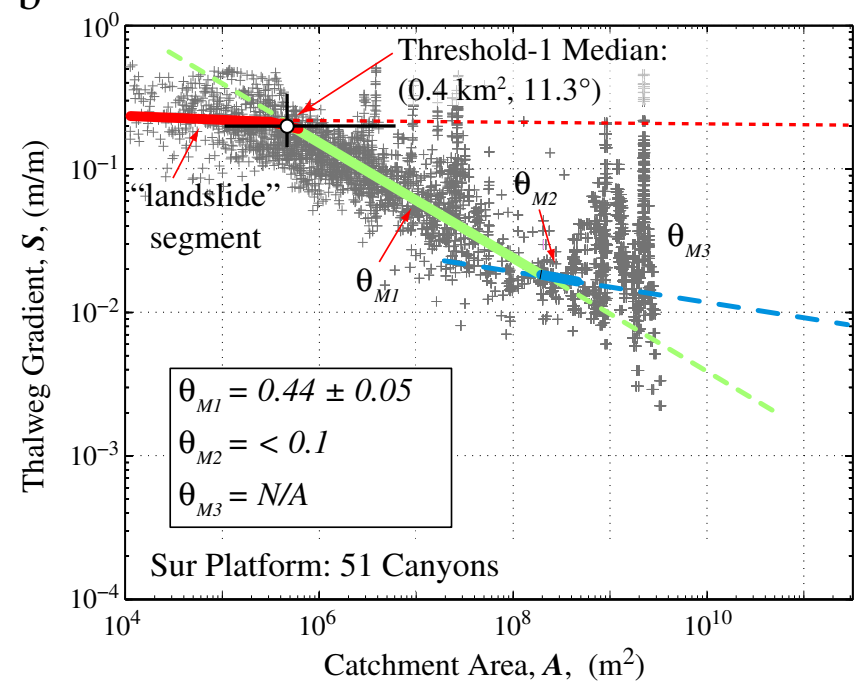

C

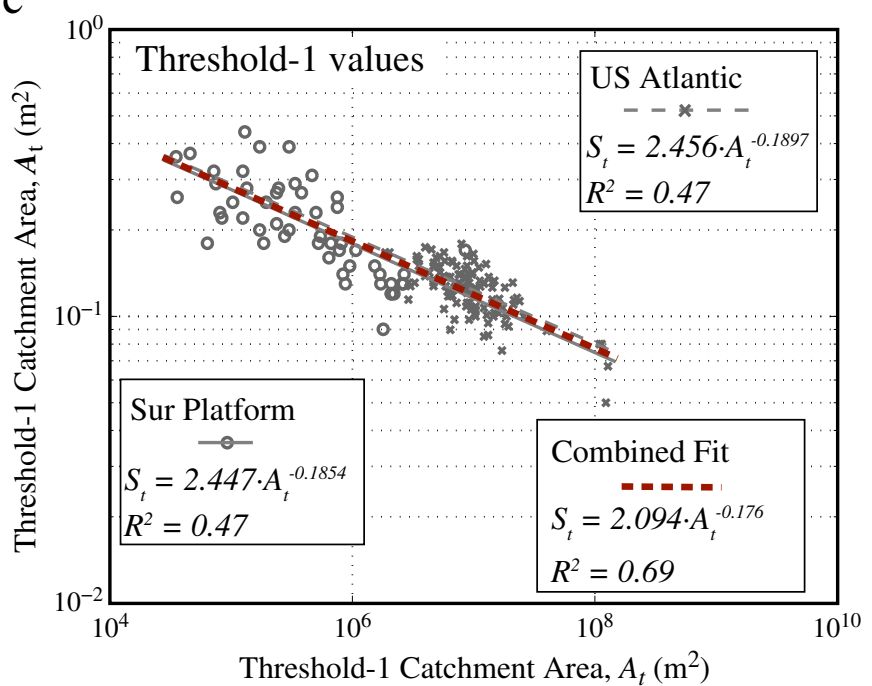

parameters (Adams and Schlager, 2000). The convex shape of interfluve profiles between the shelf-edge and $\sim 1000$ m depths (e.g., Figs. 4 and 5 ) suggests that shelf-edge and upper slope depocenters are primary sources of unstable sediment that is captured by steep canyon heads during failures.

Based on the similar structure of submarine canyons and fluvial channel networks (Figs. 2 and 9) as well as the geomorphic and geologic similarities between the USAM and the Scotian margin, we propose that threshold-1 approximates the downslope transformation of debris flows and landslides into turbidity flows. Near threshold-1, sediment failures sourced from the steep slopes above ignite into erosive turbidity flows that flush canyon-valley segments, leading to entrenchment and the higher profile concavity across the slope and uppermost rise. Based on the range of $S_{t}-A_{t}$ values associated with threshold- 1 picks (Fig. 6c), we infer that sediment failures on slope gradients less than $0.08\left(\sim 4.5^{\circ}\right)$ are unlikely to generate erosive turbidity flows.

The distributions of threshold- 1 values for the USAM and Sur Platform canyons (Fig. 6c) can be interpreted in several ways. The fact that we observe consistent and potentially predictable patterns in slope-sourced canyon morphology suggests these canyons owe their basic form to a common process that dominates over geological time scales. $S_{t}$ and $A_{t}$ values for the USAM and Sur Platform appear to define opposite ends of the same trend (Fig. 6c). If the behavior of sediment flows passing through canyons is related to the landslide catchment area, it is possible that catchment area is a proxy for total volume of sediment mobilized during significant failure events, such as those seismically triggered (Piper et al., 1999; ten Brink et al., 2009). The scatter about the regression fit (Fig. 6c) may represent spatial differences in the material properties of unstable sediment (cohesion, lithology, shear strength) and/or differences in sediment accumulation since the most recent failure event (Tucker and Bras, 1998). All factors being equal (e.g., grain size and cohesion), the generation of a debris flow and its transformation into a turbidity flow depend on the flow momentum, which is a function of the seabed gradient and the volume of failed sediment (Parker et al., 1986). The higher values for $S_{t}$ along the Sur Platform may imply that flows accelerate more rapidly on steeper slopes and ignition occurs at smaller catchment areas relative to the USAM canyons. In this scenario, preexisting physiography has an important role in the dynamic behavior of sediment flows. For example, external forcing (e.g., tectonic uplift) may be responsible for the steepness of Sur Platform landslide segments which promotes the transformation of small, localized failures to into turbidity flows at a relatively short distance away from the shelf-edge.

On the other hand, the distinctive threshold-1 distributions for the USAM and Sur Platform canyons may be caused by other factors that affect sediment flow dynamics, such as the cohesion/grain size of the failed sediment, the way flows are initiated and physiography of the continental shelf. The relatively narrow continental shelf, shallow shelf-edge and active tectonic deformation along the central California margin (Greene et al., 2002; Wong and Eittreim, 2002) are expected to have a profound influence on the nature of sediment shunted off the margin particularly during sea level low-stands. The closer proximity of canyon heads to terrestrial sediment sources and shallow water oceanographic processes along the Sur Platform may lead to failures of the uppermost slope containing higher proportions of sand, but also the potential for flow initiation along the outer shelf above the canyon heads. Sediment flows containing higher sand content are expected to dissociate and

\footnotetext{
Fig. 6. Summary of regression analysis and threshold-1 picks for all slope-sourced canyons along the USAM (a) and the Sur Platform (b). Colored segments represent average values of the regression analyses applied to each individual canyon. The median threshold-1 value for each margin is shown as a white dot and the range of associated $S_{t}$ and $A_{t}$ values as a cross-hair (see text for explanation). Regression analysis for segment $\theta_{M 3}$ was not attempted due to its highly variably nature. (c) Log-log plot of threshold-1 values for the US Atlantic Margin and the Sur Platform canyons. Regression analysis was applied separately to data from each margin and to the combined dataset.
} 

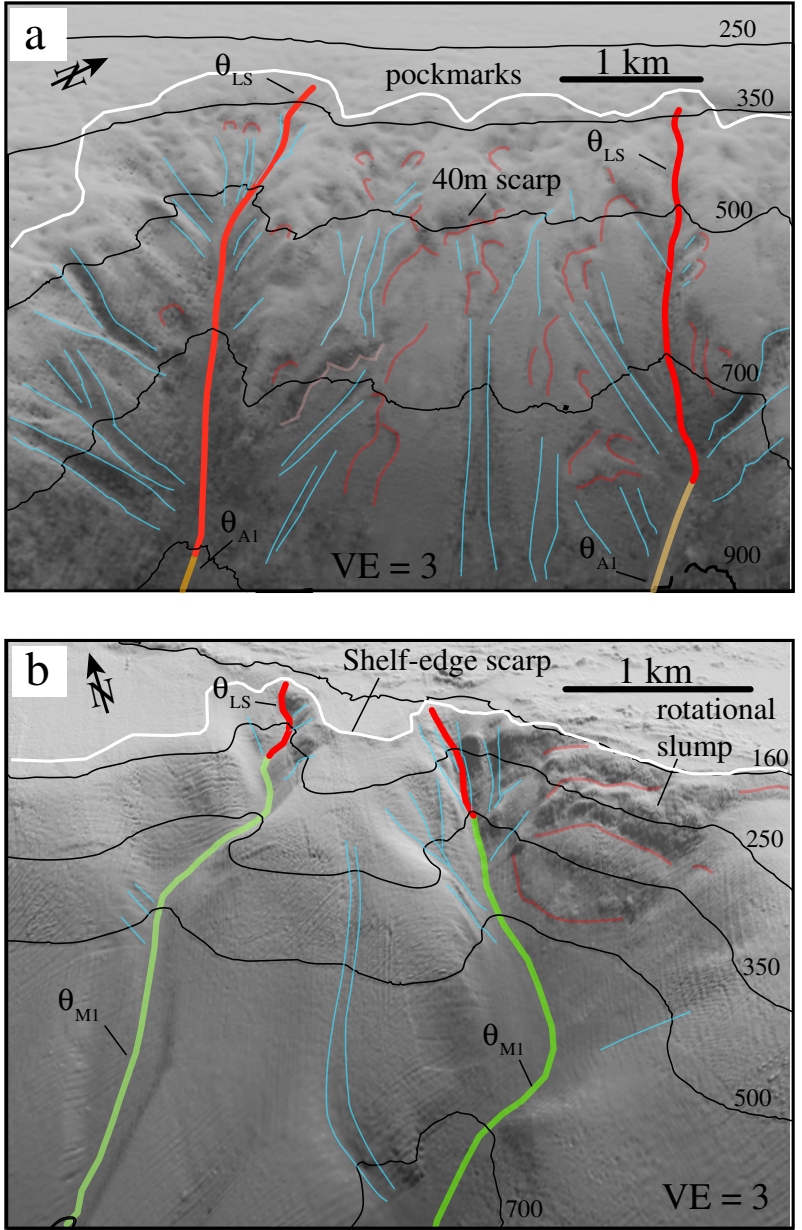

Fig. 7. Three-dimensional views of fine-scale seafloor morphology along the Mid-Atlantic slope (a; see Fig. 1 for locations) and below the Sur Platform (b). Canyon segments are colored according to their intrinsic concavities, $\theta_{i}$. Blue lines are debris flow channels, red lines are slide scars. $\theta_{L S}$ denotes the landslide segments of the canyons. Bathymetric data are gridded at $10-\mathrm{m}$ and $5-\mathrm{m}$ resolution for (a) and (b), respectively.

entrain water more rapidly than flows containing high proportions of cohesive clay (Mohrig and Marr, 2003). It is possible that sandy, shelfsourced sediment flows enter canyon heads with an initial velocity, and consequently transform into turbidity flows at relatively small catchment areas. In this scenario, our assumption that sediment flows are autogenically derived appears justified for the USAM canyons, but may not always be the case for the Sur Platform canyons. Nonetheless, extensive core and near-bottom current data in slope-sourced canyon heads of both margins are needed to test between these interpretations.

\subsection{Extracting flow properties from geomorphic scaling relations}

Recent laboratory research has expanded on ideas and observations established early (e.g., Middleton, 1966; Hampton, 1972) regarding the conditions and mechanisms that cause debris flows to transform into turbidity flows (Mohrig and Marr, 2003). Few studies have attempted to quantify the geomorphic significance of canyon heads in terms of setting the boundary conditions for erosive, canyon-flushing turbidity flows. Initial thickness and flux are fundamental parameters needed for numerical and laboratory models of sediment flow dynamics (Hampton, 1972; Parker et al., 1986; Zeng and Lowe, 1997; Mohrig et al., 1998; Mohrig and Marr, 2003) and for models of submarine canyon erosion (Gerber et al., 2009). Based on the inferred locations for major process boundaries, we develop an approach to constrain the critical thickness of geomorphically significant debris flows, $d_{c}$, at threshold-1 as a function of catchment area. To do this, we make several assumptions regarding sediment flow dynamics based on our results and early work by Hampton (1972): (1) threshold-1 marks the transformation of debris flows into turbidity flows, i.e., the transition from a laminar or near laminar density flow to a turbulent flow regime; (2) the stability of a debris flow of a particular size and velocity increases as a function of its yield strength (Hampton, 1972); (3) yield strength is exceeded and flows become turbulent when they exceed a critical velocity, however we do not make explicit assumptions about the physical mechanisms that cause the transformation into a turbid regime (Mohrig and Marr, 2003).

The critical Reynolds number, $R_{e c}$, describes a density flow as it becomes turbulent:

$R_{e c}=\frac{U_{c} d_{c}}{\kappa}$

where $U_{c}, d_{c}, K$ are the critical velocity, flow thickness and kinematic viscosity. Laboratory studies were directed at estimating $R_{e c}$ for subaqueous sediment slurries of different viscosities (Hampton, 1972; Table 2) and are supported by similar values derived from field data (e.g., Table 2 in Zeng and Lowe, 1997). Next, we use an expression for laminar flow down an open channel (Middleton, 1966),

$U_{c}=\sqrt{\frac{8 \rho^{\prime} g d_{c} \sin (\alpha)}{f}}$

where $\rho^{\prime}=\left(\rho_{\text {debris }}-\rho_{\text {water }}\right) / \rho_{\text {debris }}, g$ is gravitational acceleration, $\alpha=$ $\tan \left(S_{t}\right)$, and $f$ is the flow resistance factor. Based on assumptions (1) and (3), we combine Eq. (4) with Eq. (3) to solve for $d_{c}$ as a function of the threshold- 1 channel gradient. In other words, we can estimate the bounding conditions for critical flow thickness at the threshold in which flows become turbulent:

$d_{c}=\varepsilon \sin (\alpha)^{-1 / 3}$

Here, $\varepsilon=\left(R_{e c} \kappa\right)^{2 / 3}\left(\frac{8 \rho^{\prime} g}{f}\right)^{-1 / 3} \cdot R_{e c}$ estimates presented by Hampton (1972) were used to resolve a range of values for $\varepsilon$ (Table 2), and Eq. (5) is solved for each measured gradient, $S_{t}$, at threshold-1. Each critical thickness estimate, $d_{c}$, at threshold- 1 has an associated catchment area. Using the mean and standard deviation for $\varepsilon$, an envelope of critical thickness values is determined by least-squares regression of $d_{c}$ versus $A_{t}$ (Fig. 11): $d_{c}=(16.91 \pm 7.62) \cdot A_{t}{ }^{0.06}\left(\mathrm{R}^{2}=0.72\right)$.

Although this approach is based on several assumptions, the critical flow thickness in slope-sourced canyons is predicted to range between 15 and $85 \mathrm{~m}$ depending on the material properties assumed for the flow (e.g., yield strength). Debris flows sourced from smaller catchments traverse steeper slopes and, at the point of flow transformation, are expected to be thinner than flows from larger catchments. Within a given canyon head, or landslide catchment area, debris flows are not expected to transform into turbidity flows during every failure event, only those capable of attaining the critical thickness needed for ignition. One possibility is that earthquakes trigger simultaneous and pervasive slope failures within canyon heads. The resulting debris flows converge within the landslide catchment and provide the volume and flux needed for flows to achieve critical thickness.

Following a seismic event, such as 1929 Grand Banks (Piper et al., 1999; Piper and Normark, 2009), canyons with greater catchment areas are expected to yield relatively greater volumes and fluxes of failed sediment. The hypothetical flow discharge at threshold- 1 for such events can be estimated by multiplying the cross-sectional canyon area at a height $d_{c}$ above the canyon thalweg by the critical velocity needed for ignition (Table 2). Depending on the boundary conditions set by $\varepsilon$ and typical thalweg widths at threshold-1 (250-500 m for USAM and $100-150 \mathrm{~m}$ for Sur), flow discharge is calculated to range from 6000 to $47,000 \mathrm{~m}^{3} / \mathrm{s}$ for USAM and from 2000 to $10,500 \mathrm{~m}^{3} / \mathrm{s}$ for Sur canyons. 

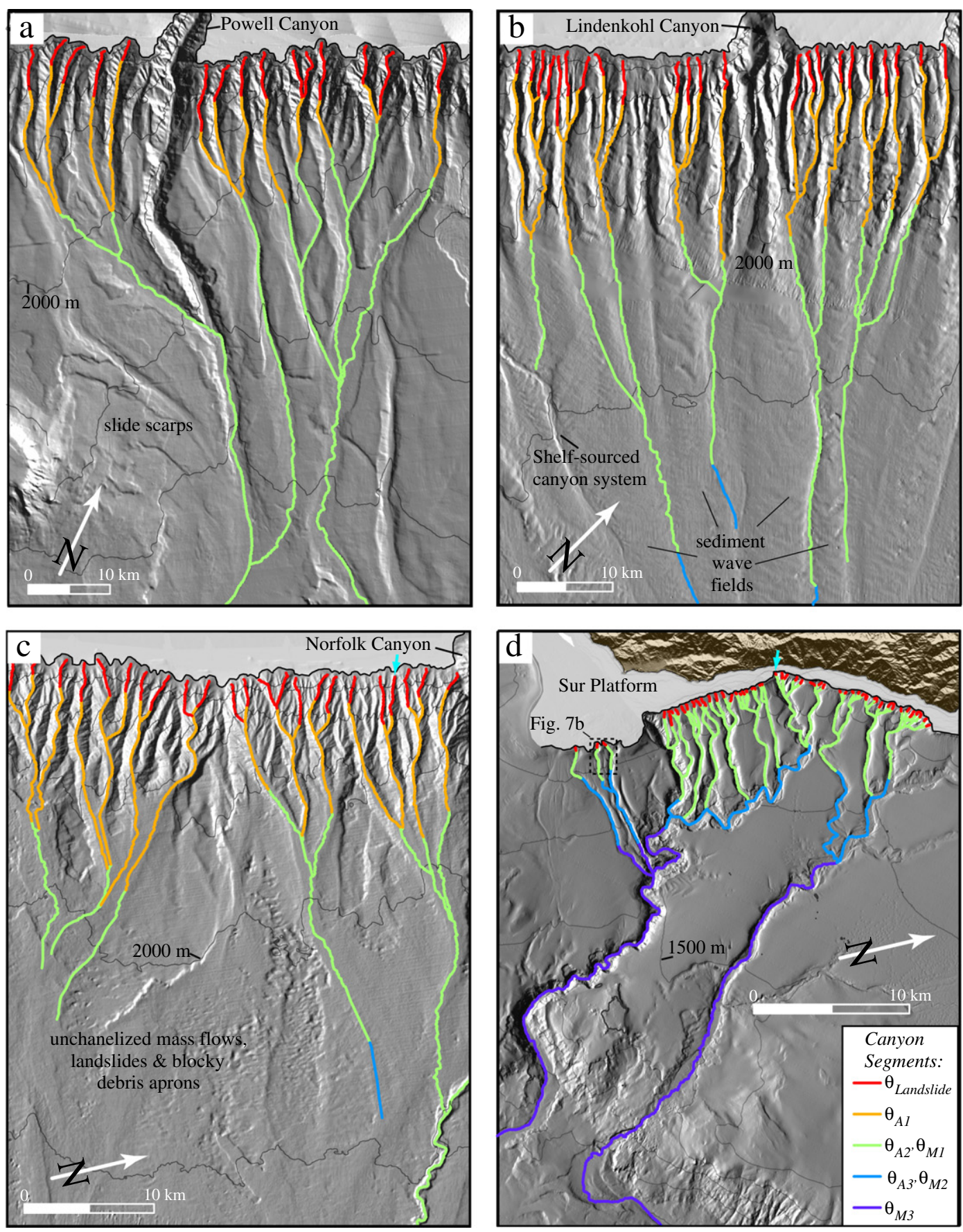

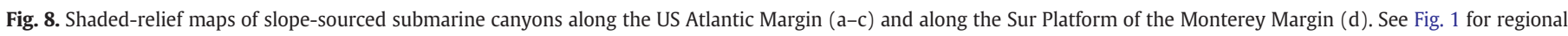

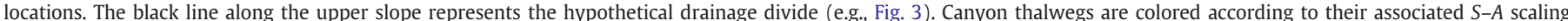

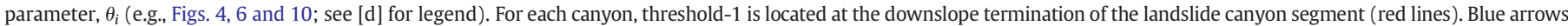
are locations of canyons shown in Fig. 4. Contours are every $500 \mathrm{~m}$.

These estimates are in line with observations from natural flows (e.g., Table 2 of Zeng and Lowe, 1997). In summary, quantitative analysis of geomorphic process boundaries in slope-sourced canyons may provide minimum bounds on the volume of sediment that is mobilized and transported to the deep sea during seismically triggered failures.

\subsection{Implications of canyon-valley domains}

Sediment entrainment/suspension models for rivers (Akiyama and Stefan, 1985) have bee applied to turbidity flows (Parker et al., 1986), suggesting that turbidity current morphodynamics in a graded canyon may be controlled by similar erosional processes as rivers. Though it may not be surprising that the range of intrinsic concavity for canyonvalley segments (0.3-0.7) is similar to that of fluvial systems (Mitchell, 2005), we do not fully understand the physical mechanisms that lead to these similarities. Sediment failures and steep gullies appear to be concentrated within the landslide domains (Twichell and Roberts, 1982; Piper and Normark, 2009), but they also occur along steep canyon walls down the entire length of canyons, meaning the cumulative volume of loose sediment supplied to canyon floors increases as a function of catchment area (analogous to increasing river discharge as a function of catchment area). If a turbidity flow remains supercritical (Froude number $>1$ ), 

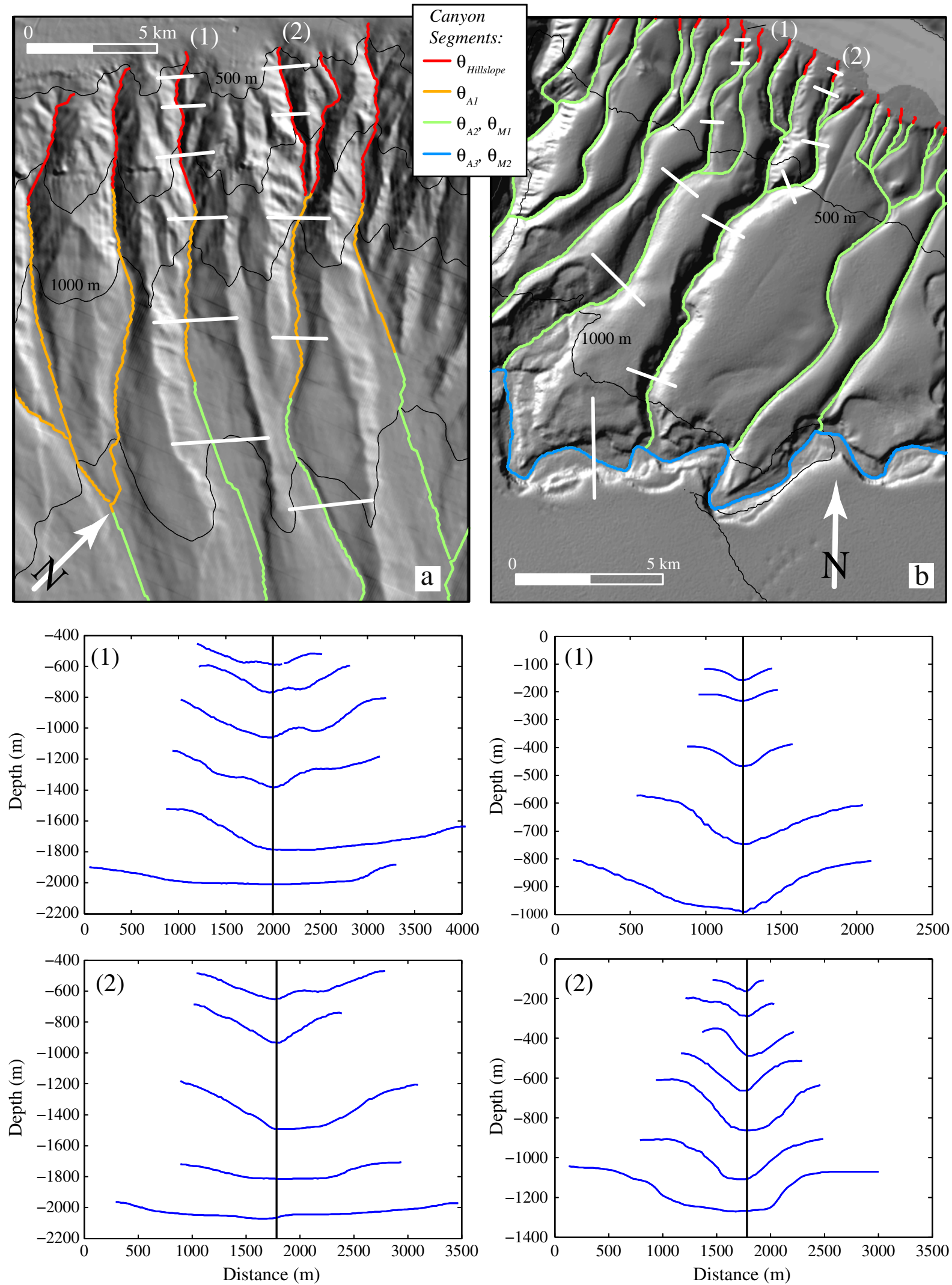

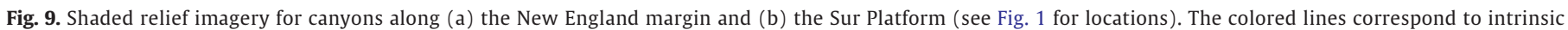

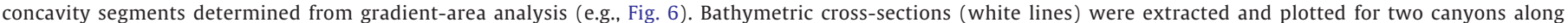
each margin to illustrate the down-slope variation in cross-sectional form. 
a

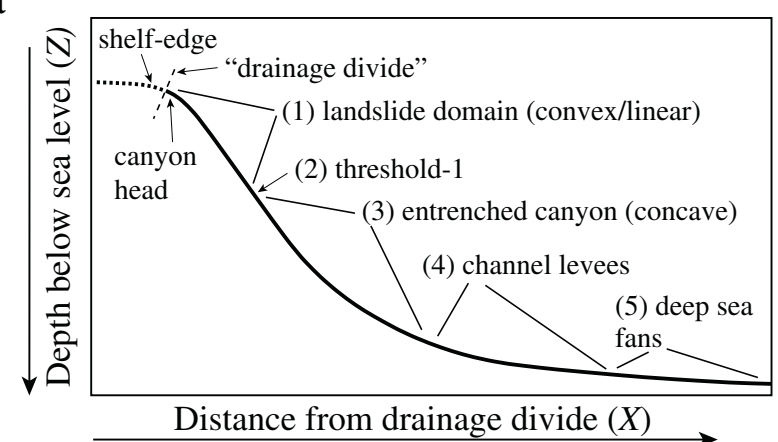

b

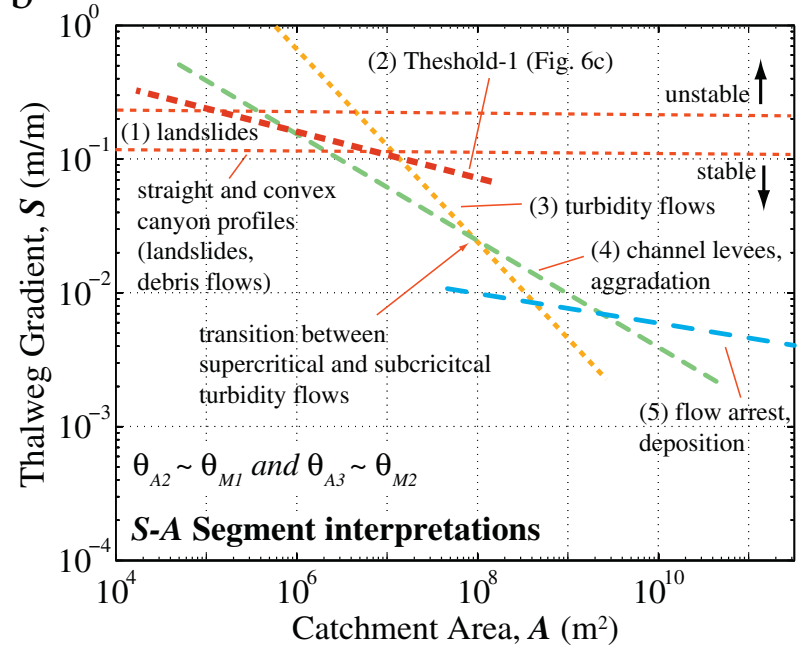

Fig. 10. (a) Hypothetical longitudinal canyon profile and associated morphological domains for a slope-sourced submarine canyon. (b) A summary of interpreted $S-A$ regression segments (see Fig. 6 and Table 1), but excluding canyon segments of extreme variation and convexity, such as along the lower slope of the Sur Platform.

it's flux may be expected to increase as it travels down canyon and entrains water and loose sediment from the canyon floor (Gerber et al., 2009).

Along the USAM, $\theta_{A 1}$ canyon segments are entrenched in the continental slope and may represent the steady-state profile for canyons formed primarily by highly erosive, supercritical turbidity flows (Mitchell, 2005) (Fig. 10b). The change in concavity between $\theta_{A 1}$ and $\theta_{A 2}$ segments is not necessarily related to sudden changes in thalweg gradient at the slope-rise transition (Garcia and Parker, 1989). In several canyons, it appears to be closely aligned with an abrupt decrease in canyon relief along the lower slope/upper rise (Figs. 4, 8a-c). Canyon relief may have a profound influence on turbidity flow evolution, including the location of hydraulic jumps along the slope-rise transition (Garcia and Parker, 1989). As canyon relief decreases near the slope-rise transition, flows are allowed to spread laterally and decrease in thickness, inducing a change from an overall erosive to an overall depositional flow regime.

Mechanically, the transition to canyon segments marked by $\theta_{A 2}$ and $\theta_{M 1}$ may represent a transformation from super-critical to subcritical flow states (Fig. 10b; Garcia and Parker, 1989). Subcritical turbidity flows transport sediment both in suspension and as bedload. Within this framework, bathymetric relief of canyons/channels dominated by subcritical turbidity flows would result from greater overbank and levee deposition than thalweg aggradation (Gerber et al., 2009). The $\theta_{A 2}$ canyon segments may represent steady-state profiles of aggradational, levee-confined channels formed by sub-critical flows across the upper continental rise. In contrast, turbidity flows sourced from the short, steep landslides below the Sur Platform may not have sufficient
Table 2

Laboratory-based measurements of mud slurries as they transition from a laminar or near laminar flow state to a turbulent regime (data from Table 1 of Hampton, 1972). Parameter $\varepsilon$ is used in the present study to estimate the critical flow thickness of canyon-confined debris flows as they are ignited into turbidity flows (Fig. 11). $\varepsilon=\left(R_{e c} \kappa\right)^{2 / 3}\left(\frac{8 \rho^{\prime} g}{f}\right)^{-1 / 3}$, where $\kappa=$ kinematic viscosity, $R_{e c}=$ critical Reynolds number, $U_{c}=$ critical velocity, $\rho^{\prime}=\left(\rho_{\text {debris }}-\rho_{\text {water }}\right) / \rho_{\text {debris }}, g=9.8 \mathrm{~m} / \mathrm{s}$, and the flow resistance factor, $f$, was set at a constant value of 0.3 based on the work by Middleton (1966). Note that a scaling factor of 4 is applied to $R_{e c}$ values from Hampton (1972) to convert from pipe flow to semi-circular channel flow (Streeter et al., 1998).

\begin{tabular}{llllr}
\hline$\kappa$ & $U_{c}$ & $\rho^{\prime}$ & $R_{e c}$ & $\varepsilon$ \\
$(\mathrm{Pa} \cdot \mathrm{s})$ & $(\mathrm{m} / \mathrm{s})$ & & & \\
\hline 0.0223 & 4.89 & 0.17 & 54,000 & 32.17 \\
0.0223 & 4.73 & 0.17 & 78,400 & 41.25 \\
0.0223 & 4.33 & 0.17 & 11,840 & 11.70 \\
0.0223 & 4.48 & 0.17 & 24,560 & 19.03 \\
0.0223 & 4.12 & 0.17 & 44,400 & 28.23 \\
0.0223 & 4.21 & 0.17 & 69,200 & 37.95 \\
0.0163 & 3.66 & 0.15 & 13,440 & 10.64 \\
0.0163 & 3.94 & 0.15 & 29,000 & 17.76 \\
0.0163 & 3.36 & 0.15 & 49,600 & 25.40 \\
0.0163 & 3.51 & 0.15 & 77,600 & 34.24 \\
0.0149 & 3.36 & 0.14 & 26,640 & 16.35 \\
0.0149 & 2.75 & 0.14 & 43,600 & 22.71 \\
0.0149 & 2.9 & 0.14 & 68,800 & 30.78 \\
0.0119 & 2.35 & 0.13 & 11,520 & 8.20 \\
0.0119 & 2.41 & 0.13 & 23,640 & 13.24 \\
0.0119 & 2.32 & 0.13 & 45,600 & 20.52 \\
0.0119 & 2.35 & 0.13 & 69,200 & 27.10 \\
0.0089 & 1.65 & 0.11 & 10,560 & 6.81 \\
0.0089 & 1.62 & 0.11 & 20,720 & 10.67 \\
0.0089 & 1.55 & 0.11 & 39,680 & 16.45 \\
0.0089 & 1.55 & 0.11 & 59,600 & 21.58 \\
Mean & 3.24 & 0.14 & 40,958 & 21.56 \\
Stdev & 1.17 & 0.02 & 22,470 & 9.71 \\
\hline
\end{tabular}

discharge or steep enough gradients along $\theta_{M 1}$ segments to maintain a supercritical state over long distances. Despite the low gradients, flows continue through the $\theta_{M 1}$ segments because they entrain loose material sourced from local failures (Greene et al., 2002) and the flows are confined by relatively high and steep canyon walls, allowing them to maintain critical thickness. Finally, the segment of nearly flat concavity, $\theta_{A 3}$, is associated with very low gradients $\left(\ll 1^{\circ}\right)$, deep-water distributary channels and, presumably, flow termination. Dramatic steepening and evidence for thalweg incision down canyon of $\theta_{M 3}$ (Figs. 4d and 8d) suggest that flows accelerate and perhaps return to a supercritical state across the lowermost slope.

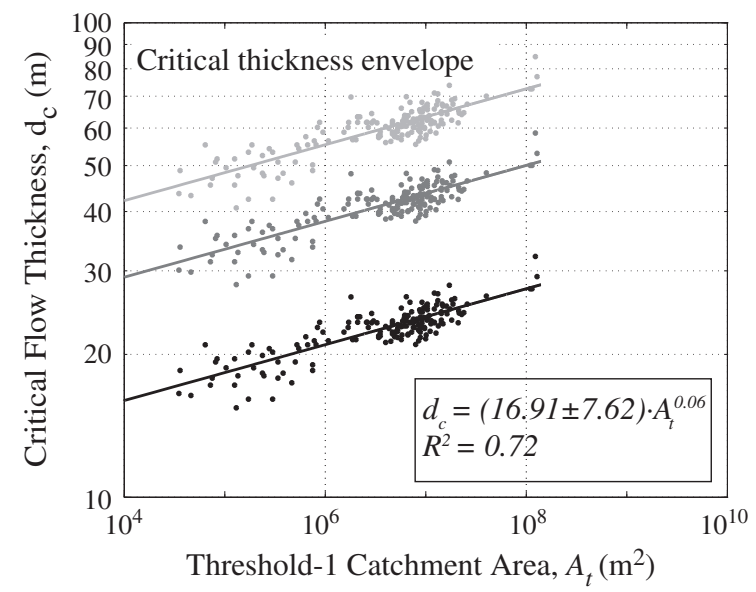

Fig. 11. Predicted thickness envelope for slope-sourced debris flows, $d_{c}$, as they transform into turbidity flows as a function of catchment area, $A_{t}$. The three curves represent a range of $d_{c}$ values that correspond to differences in material properties of debris flows (see text for details). 
A terrestrial analog for the submarine canyon segments dominated by critical versus subcritical flows may be the transitions between "transport limited" and "supply limited" conditions in river networks (Whipple and Tucker, 2002). The higher concavity and v-shaped cross sections of $\theta_{A 1}$ segments suggest that the transport capacity exceeds the canyon bed sediment supply. The $\theta_{A 2}$ and $\theta_{M 1}$ segments are associated with low gradients, and wide, flat-bottomed channels that may imply that these segments are characterized by net aggradation of the channel floors and banks.

\section{Conclusions}

Although similarities between terrestrial and submarine terrain networks raise a number of philosophical questions regarding the true meaning of terrain derived power-laws (Straub et al., 2007), we believe that such approaches can be used to (1) identify geomorphic process boundaries in either environment and (2) quantify some of the boundary conditions for sediment flows that are responsible for submarine canyon formation. The steep canyon heads along the uppermost continental slope appear to be the primary source regions for debris flows that disintegrate and transform into erosive turbidity flows. Once turbidity flows are generated, they can become self-accelerating through erosion and entrainment of loose sediment deposited along canyon floors, thus increasing in volume and erosivity in a way that is analogous to increasing discharge in river systems (Mitchell, 2005). Based on the patterns we observe, debris flows generated in canyon heads steeper than $4^{\circ}-5^{\circ}$ can transform into erosive turbidity flows as long as a critical threshold in flow thickness is exceeded. Over geological timescales, the transformation of canyon-confined debris flows into turbidity flows appears to leave behind a predictable geomorphic fingerprint (e.g., threshold-1). One possibility is that earthquakes trigger simultaneous and regionally pervasive slope failures (e.g., 1929 Grand Banks sequence of events; Piper et al., 1999) within canyon heads, thus yielding the critical volume and flux needed for debris flows to transform into turbidity flows.

Given the difficulties in obtaining in situ measurements of sediment flows, coupled with the ever-expanding volume of high-quality bathymetric data, continued efforts to develop terrain-based seascape erosion models are important. While many of the major shelf-sourced submarine canyons of the world play important roles in the geomorphic development of continental margins and in the growth of deep sea fan systems (Shepard, 1981), it is possible that the smaller, slope-sourced canyons are better suited for studies aimed at understanding relationships between form and process.

\section{Acknowledgments}

We thank the USGS Mendenhall Postdoctoral Fellowship Program and the U.S. Nuclear Regulatory Commission for supporting this work. We also thank N. Mitchell, L. Brothers and J. Denny for helpful reviews. Some of the multibeam data for this work was provided by the U.S. Extended Continental Shelf (ECS) Project. The opinions, findings, and conclusions stated herein are those of the author[s] and do not necessarily reflect those of the U.S. ECS Project. Neither the U.S. Government, the Department of the Interior, nor the USGS, nor any of their employees, contractors, or subcontractors, make any warranty, express or implied, nor assume any legal liability or responsibility for the accuracy, completeness, or usefulness of any information, apparatus, product, or process disclosed, nor represent that its use would not infringe on privately owned rights. The act of distribution shall not constitute any such warranty, and no responsibility is assumed by the USGS in the use of these data or related materials. Any use of trade, product, or firm names is for descriptive purposes only and does not imply endorsement by the U.S. Government.

\section{References}

Adams, E.W., Schlager, W., 2000. Basic types of submarine slope curvature. Journal of Sedimentary Research 70, 814-828.

Akiyama, J., Stefan, H., 1985. Turbidity-current with erosion and deposition. Journal of Hydraulic Engineering ASCE 111, 1473-1496.

Andrews, B.D., Chaytor, J.D., ten Brink, U.S., Brothers, D.S., Gardner, J.V., 2013. Bathymetric terrain model of the Atlantic Margin for marine geological investigations. U.S. Geological Survey Open-File Report, p. 2012-1266. In press.

Belderson, R.H., Stride, A.H., 1969. Shape of submarine canyon heads revealed by ASDIC. Deep Sea Research 16, 103-104.

Brothers, D.S., ten Brink, U.S., Andrews, B.D., Chaytor, J.D., in press. Geomorphic characterization of the US Atlantic continental margin. Marine Geology http://dx.doi.org/ 10.1016/j.margeo.2012.12.008.

Eittreim, S.L., Anima, R.J., Stevenson, A.J., 2002. Seafloor geology of the Monterey Bay area continental shelf. Marine Geology 181, 583-583.

Farre, J.A., McGregor, B.A., Ryan, W.B.F., Robb, J.M., 1983. Breaching the Shelfbreak: Passage from Youthful to Mature Phase in Submarine Canyon Evolution. SEPM, Tulsa, OK.

Galloway, W.E., 1998. Siliciclastic slope and base-of-slope depositional systems: component facies, stratigraphic architecture, and classification. AAPG Bulletin $82,569-595$

Garcia, M., Parker, G., 1989. Experiments on hydraulic jumps in turbidity currents near a canyon-fan transition. Science 245, 393-396.

Gardner, W.D., 1989. Baltimore canyon as a modern conduit of sediment to the deepsea. Deep-Sea Research Part A-Oceanographic Research Papers 36, 323-358.

Gerber, T.P., Amblas, D., Wolinsky, M.A., Pratson, L.F., Canals, M., 2009. A model for the longprofile shape of submarine canyons. Journal of Geophysical Research-Earth Surface 114.

Goff, J.A., 2001. Quantitative classification of canyon systems on continental slopes and a possible relationship to slope curvature. Geophysical Research Letters 28, 4359-4362.

Greene, H.G., Maher, N.M., Paull, C.K., 2002. Physiography of the Monterey Bay National Marine Sanctuary and implications about continental margin development. Marine Geology 181, 55-82.

Hampton, M.A., 1972. Role of subaqueous debris flows in generating turbidity currents. Journal of Sedimentary Petrology 42, 775-793.

Hatcher, G., Caress, D., Maher, N., Clague, D., Greene, G., Barr, N., 2000. Monterey Bay Multibeam Survey. Monterey Bay Aquarium Research Institute.

Howard, A.D., 1994. A detachment-limited model of drainage-basin evolution. Water Resources Research 30, 2261-2285.

Johnson, K.S., Paull, C.K., Barry, J.P., Chavez, F.P., 2001. A decadal record of underflows from a coastal river into the deep sea. Geology 29, 1019-1022.

Kennett, J.P., 1982. Marine Geology. Prentice Hall, Englewood Cliffs, NJ.

Kirby, E., Whipple, K., 2001. Quantifying differential rock--uplift rates via stream profile analysis. Geology 29, 415-418.

Kneller, B., Buckee, C., 2000. The structure and fluid mechanics of turbidity currents: a review of some recent studies and their geological implications. Sedimentology 47, $62-94$.

Mcgregor, B., Stubblefield, W.L., Ryan, W.B.F., Twichell, D.C., 1982. Wilmington-Submarine Canyon - a marine fluvial-like system. Geology 10, 27-30.

Middleton, G.V., 1966. Experiments on density and turbidity currents II: uniform flow of density currents. Canadian Journal of Earth Sciences 3, 627-637.

Mitchell, N.C., 2004. Form of submarine erosion from confluences in Atlantic USA continental slope canyons. American Journal of Science 304, 590-611.

Mitchell, N.C., 2005. Interpreting long-profiles of canyons in the USA Atlantic continental slope. Marine Geology 214, 75-99.

Mitchell, N.C., Huthnance, J.M., 2007. Comparing the smooth, parabolic shapes of interfluves in continental slopes to predictions of diffusion transport models. Marine Geology 236, 189-208.

Mohrig, D., Marr, J.G., 2003. Constraining the efficiency of turbidity current generation from submarine debris flows and slides using laboratory experiments. Marine and Petroleum Geology 20, 883-899.

Mohrig, D., Whipple, K.X., Hondzo, M., Ellis, C., Parker, G., 1998. Hydroplaning of subaqueous debris flows. Geological Society of America Bulletin 110, 387-394.

Mosher, D., Piper, D., 2007. Analysis of multibeam seafloor imagery of the Laurentian Fan and the 1929 Grand Banks landslide area. In: Lykousis, V., Sakellariou, D., Locat, J. (Eds.), Submarine Mass Movements and Their Consequences. Springer, Amsterdam, pp. 77-88.

Mulder, T., Syvitski, J.P.M., 1995. Turbidity currents generated at river mouths during exceptional discharges to the world oceans. Journal of Geology 103, 285-299.

Parker, G., Fukushima, Y., Pantin, H.M., 1986. Self-accelerating turbidity currents. Journal of Fluid Mechanics 171, 145-181.

Paull, C.K., Ussler, W., Greene, H.G., Keaten, R., Mitts, P., Barry, J., 2003. Caught in the act: the 20 December 2001 gravity flow event in Monterey Canyon. Geo-Marine Letters 22, 227-232.

Paull, C.K., Caress, D.W., Ussler, W., Lundsten, E., Meiner-Johnson, M., 2011. High-resolution bathymetry of the axial channels within Monterey and Soquel submarine canyons, offshore central California. Geosphere 7, 1077-1101.

Paull, C.K., Caress, D., Lundsten, E., Gwiazda, R., Anderson, K., McGann, M., Conrad, J., Edwards, B.D., Sumner, E.J., 2013. Anatomy of the La Jolla Submarine Canyon system; offshore southern California. Marine Geology 334, 16-34.

Piper, D.J.W., Normark, W.R., 2009. Processes that initiate turbidity currents and their influence on turbidites: a marine geology perspective. Journal of Sedimentary Research 79, 347-362.

Piper, D.J.W., Savoye, B., 1993. Processes of Late Quaternary turbidity-current flow and deposition on the Var Deep-Sea Fan, North-West Mediterranean-Sea. Sedimentology $40,557-582$. 
Piper, D.J.W., Cochonat, P., Morrison, M.L., 1999. The sequence of events around the epicentre of the 1929 Grand Banks earthquake: initiation of debris flows and turbidity current inferred from sidescan sonar. Sedimentology 46, 79-97.

Pirmez, C., Imran, J., 2003. Reconstruction of turbidity currents in Amazon Channel. Marine and Petroleum Geology 20, 823-849.

Pirmez, C., Pratson, L.F., Steckler, M.S., 1998. Clinoform development by advection-diffusion of suspended sediment: modeling and comparison to natural systems. Journal of Geophysical Research-Solid Earth 103, 24141-24157.

Pratson, L.F., Coakley, B.J., 1996. A model for the headward erosion of submarine canyons induced by downslope-eroding sediment flows. Geological Society of America Bulletin 108, 225-234.

Pratson, L.F., Ryan, W.B.F., 1996. Automated drainage extraction in mapping the Monterey Submarine Drainage System, California margin. Marine Geophysical Researches 18, 757-777.

Pratson, L.F., Ryan, W.B.F., Mountain, G.S., Twichell, D.C., 1994. Submarine-canyon initiation by downslope-eroding sediment flows - evidence in Late Cenozoic strata on the New-Jersey continental slope. Geological Society of America Bulletin 106, 395-412.

Puig, P., Ogston, A.S., Mullenbach, B.L., Nittrouer, C.A., Parsons, J.D., Sternberg, R.W. 2004. Storm-induced sediment gravity flows at the head of the Eel submarine canyon, northern California margin. Journal of Geophysical Research-Oceans 109.

Ramsey, L.A., Hovius, N., Lague, D., Liu, C.S., 2006. Topographic characteristics of the submarine Taiwan orogen. Journal of Geophysical Research-Earth Surface 111

Seidl, M.A., Dietrich, W.E., 1992. The problem of channel erosion into bedrock. Catena Supplement 23, 101124.

Shepard, F.P., 1981. Submarine canyons: multiple causes and long-time persistence. AAPG Bulletin 65, 1062-1077.

Shepard, F.P., Emery, K.O., 1973. Congo submarine canyon and fan valley. American Association of Petroleum Geologists Bulletin 57, 1679-1691.

Stock, J., Dietrich, W.E., 2003. Valley incision by debris flows: evidence of a topographic signature. Water Resources Research 39.

Straub, K.M., Jerolmack, D.J., Mohrig, D., Rothman, D.H., 2007. Channel network scaling laws in submarine basins. Geophysical Research Letters 34.
Streeter, V.L., Wylie, E.B., Bedford, K.W., 1998. Fluid Mechanics, 9th ed. WCB/McGraw Hill, Boston.

ten Brink, U.S., Barkan, R., Andrews, B.D., Chaytor, J.D., 2009. Size distributions and failure initiation of submarine and subaerial landslides. Earth and Planetary Science Letters 287, 31-42.

Tucker, G.E., Bras, R.L., 1998. Hillslope processes, drainage density, and landscape morphology. Water Resources Research 34, 2751-2764.

Tucker, G.E., Whipple, K.X., 2002. Topographic outcomes predicted by stream erosion models: sensitivity analysis and intermodel comparison. Journal of Geophysical Research-Solid Earth 107.

Twichell, D.C., Roberts, D.G., 1982. Morphology, distribution, and development of submarine canyons on the United-States Atlantic continental-slope between Hudson and Baltimore canyons. Geology 10, 408-412.

Whipple, K.X., Tucker, G.E., 1999. Dynamics of the stream-power river incision model: Implications for height limits of mountain ranges, landscape response timescales, and research needs. Journal of Geophysical Research-Solid Earth 104, 17661-17674.

Whipple, K.X., Tucker, G.E., 2002. Implications of sediment-flux-dependent river incision models for landscape evolution. Journal of Geophysical Research-Solid Earth 107.

Willgoose, G., Bras, R.L., Rodriguez-Iturbe, I., 1991a. A coupled channel network growth and hillslope evolution model.1. Theory. Water Resources Research 27, 1671-1684.

Willgoose, G., Bras, R.L., Rodriguez-Iturbe, I., 1991b. A physical explanation of an observed link area-slope relationship. Water Resources Research 27, 1697-1702.

Wobus, C., Whipple, K.X., Kirby, E., Snyder, N.P., Johnson, J., Spyropolou, K., Crosby, B.T. Sheehan, D., 2006. Tectonics from topography: procedures, promise, and pitfalls. Geological Society of America Special Paper 398, 55-74.

Wong, F.L., Eittreim, S.L., 2002. Continental shelf GIS for the Monterey Bay National Marine Sanctuary. Marine Geology 181, 317-321.

Xu, J.P., Noble, M.A., Rosenfeld, L.K., 2004. In-situ measurements of velocity structure within turbidity currents. Geophysical Research Letters 31

Zeng, J.J., Lowe, D.R., 1997. Numerical simulation of turbidity current flow and sedimentation. 1 . Theory. Sedimentology 44, 67-84. 